Pegem Eğitim ve Öğretim Dergisi, 11(1), 2021, 217-258

www.pegegog.net

\title{
Teacher abuse, school burnout and school attachment as predictors of adolescents' risky behaviors
}

\author{
Firdevs SAVI ÇAKAR ${ }^{* a}$, Kıvanç UZUN ${ }^{* *_{a}}$
}

${ }^{a}$ Burdur Mehmet Akif Ersoy University, Faculty of Education, Burdur/Turkey

CrossMark

\begin{tabular}{l}
\hline Article Info \\
\hline DOI: $10.14527 /$ pegegog.2021.007 \\
\hline Article History: \\
Received $\quad 04$ July 2020 \\
Revised $\quad 29$ November 2020 \\
Accepted $\quad$ 02 January 2021 \\
Online $\quad 29$ January 2021 \\
\hline Keywords: \\
Adolescents, \\
Risky behaviors, \\
Teacher abuse, \\
School burnout, \\
School attachment. \\
\hline Article Type: \\
Research paper
\end{tabular}

\begin{abstract}
The aim of this study is to determine the predictive level of teacher abuse, school burnout and school attachment for risky behaviors in adolescents, and to examine risky behaviors according to some demographic variables. Relational survey model was employed in the study. The study group consisted of 446 adolescents with an average age of 15.49 years studying in secondary schools. Personal information form, Risky Behaviors Scale, Teacher Emotional Abuse Scale, School Burnout Scale and School Attachment Scale for Adolescents were used to obtain demographic information about students. As for data analysis, Pearson's Correlation Coefficient Analysis, Multiple Linear Regression Analysis, Independent Samples t-Test and One-Way Variance Analysis were employed. As a result, it was found that teacher abuse and school burnout predicted adolescents' risky behaviors in a positively significant direction whereas school attachment predicted adolescents' risky behaviors in a negatively significant direction. It was revealed that the score averages taken from the total and sub-dimensions of risky behaviors differed significantly according to gender, grade level, academic average, perceived socioeconomic level and family structure variables. In addition, it was determined that suicidal tendencies did not differ based on gender, academic average and class level; antisocial behaviors and school dropout did not significantly differ according to the grade level.
\end{abstract}

\section{Ergenlerde riskli davranışların yordayıcıları olarak öğretmen istismarı, okul} tükenmişliği ve okula bağlanma

\section{Makale Bilgisi}

DOI: $10.14527 /$ pegegog.2021.007

Makale Geçmişi:

Geliş $\quad 04$ Temmuz 2020

Düzeltme 29 Kasım 2020

Kabul 02 Ocak 2021

Çevrimiçi 29 Ocak 2021

Anahtar Kelimeler:

Ergenler,

Riskli davranışlar,

Öğretmen istismarı,

Okul tükenmişliği,

Okula bağlanma.

Makale Türü:

Özgün makale

\section{Öz}

Bu araştırmanın amacı, ergenlerde öğretmen istismarı, okul tükenmişliği ve okula bağlanmanın riskli davranışları yordama düzeyinin belirlenmesi ve riskli davranışların bazı demografik değişkenlere göre incelenmesidir. Araştırmada ilişkisel tarama modeli kullanılmıştır. Çalışma grubu ortaöğretim kurumlarında öğrenim gören ve yaş ortalaması 15.49 olan 446 ergenden oluşmaktadır. Veri toplama araçları olarak öğrencilere ilişkin demografik bilgilerin elde edildiği kişisel bilgi formu, Riskli Davranışlar Ölçeği, Öğretmen Duygusal İstismar Ölçeği, Okul Tükenmişliği Ölçeği ve Ergenler için Okula Bağlanma Ölçeği kullanılmıştır. Verilerin analizinde Pearson Korelasyon Katsayısı Analizi, Çoklu Doğrusal Regresyon Analizi, İlişkisiz Örneklemler tTesti ve Tek Yönlü Varyans Analizi kullanılmıştır. Sonuç olarak, öğretmen istismarı ve okul tükenmişliğinin ergenlerin riskli davranışlarını pozitif yönde; okula bağlanmanın ise negatif yönde ve anlamlı düzeyde yordadığı görülmüştür. Ayrıca, riskli davranışların toplam ve alt boyutlarından alınan puan ortalamalarının cinsiyet, sınıf düzeyi, akademik ortalama, algılanan sosyoekonomik düzey ve aile yapısı değişkenlerine göre anlamlı düzeyde farklılaşmaktadır. Diğer taraftan intihar eğiliminin cinsiyet, akademik ortalama ve sınıf düzeyine göre; antisosyal davranışların ve okul terkinin ise sınıf düzeyine göre anlamlı düzeyde farklılaşmadığı belirlenmiştir.
Author: firdevssavi@mehmetakif.edu.tr Author: kuzun@mehmetakif.edu.tr
Orcid ID: https://orcid.org/0000-0001-8536-3625

Orcid ID: https://orcid.org/0000-0002-6816-1789 


\section{Introduction}

It is important to define the aims and functions of risky behaviors in terms of adolescent development and compliance process and to focus on strengthening adolescent mental health through protective and preventive studies. With the repercussions of rapid and unpredictable changes in the world, it is clear that adolescence can become a much more challenging process when added to the turmoil created by the periodic psychosocial struggles that adolescents have to deal with. Therefore, understanding the causes of the orientation to risky behaviors that occur frequently in adolescents can be considered an important need in both adolescent studies and mental health studies.

In problem behavior theory from approaches that address the risky behavior of adolescents, risky behaviors are defined as "behaviors that are life-threatening or health-threatening to adolescents, which are likely to result in illness, injury or death." In addition, it is emphasized that risky behaviors serve some purposes in adolescents' lives, and motivation is important in the orientation of risky behaviors; it focuses on factors (protective factors) that increase the likelihood of adolescents exhibiting problem behaviors (risk factors) and prevent them (Jessor, 1991). According to the theory of social learning, which considers the risky behavior of adolescents, social factors such as family and peers are very important in the formation of risky behaviors. Accordingly, the focus should be on factors such as the orientation of adolescents to risky behaviors, learning through observation, self-suffering belief, seeking excitement, risk-taking behavior and resisting perceived peer influence (Bandura, 2006). In the theory of social control, which dealt with the risky behavior of adolescents, Hirschi (2002) explained risky behaviors with a decrease in the link between adolescents and society, while arguing that adolescents' orientation to risky behavior will be reduced through their bonds with school, family and friends. In addition, in the ecological approach, Bronfenbrenner (1979) discussed the effects of environmental factors on adolescent development from a broad perspective that extends from the interaction between parent adolescents to their farther factors, such as culture. In this context, Bronfenbrenner (1979) focuses on interactions between the environmental systems of adolescents and adolescents while explaining risky behaviors. As clearly emphasized in all these theories, different factors play a role in the emergence of adolescent risky behaviors.

The focus should be on adolescents' risky behaviors since these behaviors are responsive and carry continuity (Ögel, Akço, Aksoy, Dönmez, Yılmazçetin, Erdoğan et al., 2007), adolescents perform risky behaviors without predicting their consequences (Siyez, 2009), but also because multiple risky behaviors are likely to be seen together (Lindberg, Boggess, Porter, \& Williams, 2000). Risky behaviors evaluated in this context often include antisocial behaviors, alcohol, smoking, cannabis and other drug use, physical assault, suicidal thoughts and attempts, risky sexual behaviors, as well as risky sexual behaviors, and many problem behaviors such as school dropout (Jessor, 1991; Lindberg et al., 2000; Ögel et al., 2007). The common characteristics of these behaviors are that each has the potential to result in a number of health problems that can develop in an abrupt or long time, not being considered appropriate by society, preventing adolescents from fulfilling their developmental duties and social roles, gaining a sense of success and competence (Jessor, 1991; Jessor, Donovan, \& Costa, 1994; Lindberg et al., 2000). In this context, it is important to focus on effective prevention and intervention efforts by evaluating the effect of adolescent risky behavior on adolescents' development and adaptation, as well as short-term and long-term effects. Focusing on and adequately meeting the increasing psychological assistance needs of adolescents during this period will play a protective and preventive role in many areas, especially risky behaviors (Savi-Çakar \& Kılınç, 2020).

In studies assessing the effect of risky behaviors on adolescent development and compliance; protective and risk factors (Jessor et al., 1994; Siyez, 2009); social support (ikiz \& Savi-Çakar, 2012; SaviÇakar \& Tagay, 2017); family functions (Çataloglu, 2011); causes of risky behavior (Savi-Çakar, Tagay, \& Karataş, 2015); levels of peer bullying and psychological well-being (Özdemir, 2018); subjective wellbeing and self-esteem (Savi-Çakar \& Tagay, 2017); the focus is on variables such as loss and grief, strategies for improving subjective well-being and emotion editing skills (Akyüz, 2019) and parental and teacher abuse (Cansız, 2019). In addition, it is observed that negative life events and cognitive emotion 
regulation (Garnefski, Kraaij, \& Spinhoven, 2001), environmental risk factors (Gerard \& Buehler, 2004), self-control (Quinn \& Fromme, 2010), depression and suicidal tendencies (Campos \& Mesquita, 2014), sociodemographic variables, psychological health (Piko, 2000); physical abuse (Perkins \& Jones, 2004); peer support (Brendgen, Lamarche, Wanner, \& Vitaro, 2010); adolescent communication with the family (Gutman, Eccles, Peck, \& Malanchuk, 2011), academic failure (Girma, Hassen, \& Garuma, 2019; PérezFuentes, Gázquez, Mercader, \& García-Rubira, 2011) and genetic factors (Harden, Quinn, \& Tucker-Drob, 2012) have been examined. Based on these studies, it can be said that adolescent risky behaviors need to be handled in a multifaceted way in relation to many variables. In this context, adolescent risky behaviors will be examined in terms of school burnout, school attachment and teacher abuse.

In this study, school burnout, among variables to be evaluated with its relationship with risky behaviors, describes a very common condition in education with symptoms such as fatigue, desensitization, apathy (Salmela-Aro, Savolainen, \& Holopainen, 2009). Academic pressure experienced is also an important issue for adolescents in terms of causing academic stress (Yang \& Farn, 2005) and negatively affecting mental health (Salmela-Aro, Upadyaya, Hakkarainen, Lonka, \& Alho, 2017). In this context, among the variables discussed with school burnout in adolescents in the literature; researchers seem to focus on problems such as risky behaviors (Salmela-Aro \& Upadyaya, 2014), depression (Salmela-Aro et al., 2009), psychological dissonance (Lee \& Lee, 2018), school leave (Yang \& Farn, 2005), peer bullying (Uzun \& Karataş, 2019).

Another important variable that should be evaluated in terms of risky behaviors in terms of school is school attachment. School attachment is explained in a broad context that reflects the belief in value and proficiency for school activities, and also addresses student motivation and extracurricular activities at school (Faircloth \& Hamm, 2005). Adolescent's school attachment meets basic psychological requirements such as feeling of being valued and respected as a member of the school (Roeser \& Eccles, 2000) and establishing emotional connection through relationships with teachers and classmates at the school (Eccles \& Roeser, 1999). As a social bonding area, the school promotes positive mental health development (Roeser \& Eccles, 2000). In the above explanations, it is seen that school attachment contributes significantly to adolescent development and adaptation. It is observed that studies conducted in this context discuss school attachment in relation to risky behaviors (Diaz, 2005; Rudasill, Reio, Stipanovic, \& Taylor 2010; Savi-Çakar, 2018).

Another variable in the study related to risky behaviors is teacher abuse; this variable consists of physical, emotional, sexual and economic abuse that cause physical, emotional, sexual and economic harm to the child's life, development, health or dignity. Abuse and neglect with cognitive, emotional, physical and social effects on children is a common problem all over the world with irrecoverable consequences (WHO Report, 1999). Abuse is not only limited to parents of children and adolescents, but is also associated with the wider social environment in which it is included, and the problem of teacher abuse is frequently encountered in school environment (Hyman \& Snook, 1999; Theoklitou, Kabitsis, \& Kabitsi, 2012). Many emotional, behavioral, developmental and social problems and suicide attempts can be seen in children and adolescents who have been abused (Taner \& Gökler, 2004). However, it is stated that adolescents exhibit self-harm behavior (D'Onofrio, 2007) and risky behaviors to relieve psychological distress and suffering due to abuse (Arnow, 2004; Chen \& Liao, 2005; Fry, McCoy, \& Swales, 2012; Young \& Widom, 2014). For this reason, it is thought that perceived abuse from the teacher will be important in explaining the orientation to risky behaviors in adolescents.

It may be useful to study risky behaviors in relation to both living spaces (family, school, peer and community) and many negative outcomes since these behaviors include those contrary to legal and social norms, disapproval by culture, against authority, and expressed as problems within the social structure (Jessor, 1991; Jessor et al., 1994). In this context, risky behaviors can negatively affect adolescent's school life, as well as contribute to the emergence of risky behaviors in school life and school-related variables. Among these variables, teacher abuse, school burnout and school attachment level are thought to be important in explaining adolescent risky behavior. 
The aim of this study is to determine the predictive level of teacher abuse, school burnout and school attachment for risky behaviors in adolescents, and to examine risky behaviors according to some demographic variables.

The problem of the study is "Do teacher abuse, school burnout and school attachment variables significantly predict adolescents' risky behaviors?".

The sub-problems of the research are as follows:

- Do the levels of teacher abuse, school burnout, and school attachment significantly predict adolescents' risky behaviors?

- Do adolescents' risky behaviors vary significantly according to gender, class level, academic average, perceived socioeconomic level and family structure?

\section{Method}

\section{Research Design}

Relational survey model was employed in the study. Relational survey models are research model that aims to determine the presence and degree of change between two or more variables (Karasar, 2012).

\section{Study Group}

The working group of the research consisted of 446 students who studied in secondary schools in Bodrum district of Muğla province and had an average age of 15.49 in the 2019-2020 academic year. When selecting the sample, stratified sampling methods were used, which is among random sampling methods. Stratified layered sampling is a sampling method that aims to identify sub-groups in a universe and ensure that they are represented in the sample by their proportions within the size of that universe (Büyüköztürk, Kılıç-Çakmak, Akgün, Karadeniz, \& Demirel, 2016). In this context, possibilities and limitations (time, money, etc.) were calculated from the 4460 students in the study universe; it was decided to create a $10 \%$ sample thought to be the power of representation of the universe (Özen \& Gül, 2007).

The proportion of groups in the sample of 446 people created was determined by the formula and sample calculation specified in Table 1 (Özen \& Gül, 2007).

Table 1.

Sample Calculation Formula

\begin{tabular}{lccc}
\hline & $\begin{array}{c}\text { Number in the } \\
\text { Universe }\end{array}$ & Layer Weight & $\begin{array}{c}\text { Number of Girls to be included in } \\
\text { Sample }\end{array}$ \\
\hline Gender & $\mathrm{Ni}$ & $\mathrm{Ni} / \mathrm{N}=\mathrm{ai}$ & ai $\times \mathrm{n}=\mathrm{ni}$ \\
Female & 2319 & $2319 / 4460=.52$ & $.52 \times 446=235$ \\
\hline
\end{tabular}

Students' participation in the research was based on voluntariness. Demographic information on the study group is presented in Table 2 . When Table 2 is examined, it is seen that $52.70 \%(n=235)$ of the participants are girls, and $42.30 \%(n=221)$ of them are boys. Among research participants, $27.13 \%$ $(n=121)$ are 9th grader, $22.86 \%(n=102)$ 10th grader, $23.54 \%(n=105)$ 11th grader, and $26.45 \%(n=116)$ 12th grader. Among research participants, $11.09 \%(n=53)$ have an academic grade point average of 49 and below, 37.70\% $(n=168)$ average between 50-69, 36.10\% $(n=161)$ an average between $70-84 \%$, and $14.30 \%(n=64)$ an average of 85 and higher. 19.95\% $(n=89)$ of participants defined their socioeconomic status as poor, $39.46 \%(n=176)$ as moderate, and $40.58 \%(n=181)$ as good. The parents of $46.18 \%$ $(n=206)$ of the participants live together, while parents of $32.06 \%(n=143)$ of the participants have divorced, and mothers and/or fathers of $21.74 \%(n=97)$ of the participants have died. 
Table 2.

Descriptive Statistical Findings on the Sample

\begin{tabular}{llrr}
\hline Factor & Variable & $\mathbf{n}$ & $\mathbf{\%}$ \\
\hline Gender & Female & 235 & 52.70 \\
Grade Level & Male & 211 & 42.30 \\
& 9th Grade & 121 & 27.13 \\
& 10th grade & 102 & 22.86 \\
& 11th grade & 105 & 23.54 \\
Academic Average & 12th Grade & 118 & 26.45 \\
& 49 and lower & 53 & 11.09 \\
& Between 50-69 & 168 & 37.70 \\
SES & Between 70-84 & 161 & 36.10 \\
& 85 and higher & 64 & 14.30 \\
Family Structure & Poor & 89 & 19.95 \\
& Moderate & 176 & 39.46 \\
Total Number of Studen & Good & 181 & 40.58 \\
\hline
\end{tabular}

\section{Data Collection Tools}

In the study, data collection tools included the personal information form, Risky Behaviors Scale, Teacher Emotional Abuse Scale, School Burnout Scale and School Attachment Scale for Adolescents to obtain demographic information about students. For all data collection tools used in the research, permissions were taken from intellectual rights owners by e-mail. In addition, the necessary permissions were obtained from Bodrum District National Education Directorate to carry out the research in a healthy manner. For the participating students, necessary information has been given on research and scales.

Personal Information Form: A personal information form was created by the researchers to learn about demographic characteristics of the students participated in the study. Personal information (gender, class level, academic average, perceived socioeconomic status, family structure) are included in the personal information form.

Risky Behaviors Scale (RBS): The scale was developed by Gençtanırım and Ergene (2014) to measure adolescents' risky behavior. The scale is in 5-item Likert type consisting of a total of 36 items. A rise in the score from the scale indicates that the level of individual's risky behavior also rises. The scale has six sub-dimensions that measure 'antisocial behaviors' (7 items), 'alcohol abuse' (7 items), 'smoking' (6 items), 'suicidal tendencies' (4 items), 'feeding habits' (5 items) and 'school leave' ( 7 items), and a total point can be obtained from the scale. The scale explains $55.43 \%$ of the total variant. The overall internal consistency coefficient of the RBS is .90 (Gençtanırım \& Ergene, 2014).

To use the RBS within the scope of this study, reliability and validity studies were carried out first. For reliability study, the Cronbach's alpha consistency coefficient of the scale was calculated and found to be .93. Confirmatory Factor Analysis (CFA) was performed to test the structure validity of the scale, and it was found that fit indices were significant $\left(X^{2}=920.64, s d=324, p=.00, X^{2} / s d=2.84, R M S E A=.07\right.$, $\mathrm{SRMR}=.08, \mathrm{CFI}=.92, \mathrm{NNFI}=.91$ ). Considering these values, it can be said that the scale is reliable and valid enough to be used in research (Kline, 2014). 
Teacher Emotional Abuse Scale (TEAS): TEAS was developed by Kırımsoy and Kaner (2001) to measure teachers' level of emotional abuse on adolescents. The scale is in 5-item Likert type consisting of a total of 27 items. A rise in the score from the scale indicates that individual is exposed to teacher abuse at an intense rate. The scale has three sub-dimensions that measure 'rejection and humiliation' (9 items), 'intimidation' ( 9 items) and 'insensitivity' ( 9 items), and a total score can be obtained from the scale. The overall internal consistency coefficient of the TEAS is .70 (Kırımsoy \& Kaner, 2001; as cited in Kırımsoy, 2003).

To use TEAS within the scope of this study, reliability and validity studies were carried out first. For reliability study, the Cronbach's alpha consistency coefficient of the scale was calculated and found to be .83. CFA was performed to test the structure validity of the scale, and it was found that fit indices were significant $\left(X^{2}=2365.54, s d=827, p=.00, X^{2} / s d=2.86, R M S E A=.07, S R M R=.09, C F I=.90, N N F I=.92\right)$. Considering these values, it can be said that the scale is reliable and valid enough to be used in research (Kline, 2014).

School Burnout Scale (SBS): SBS was developed by Salmela-Aro, Kiuru, Leskinen and Nurmi (2009) to measure students' school burnout. The adaptation of the scale into Turkish culture was made by Seçer, Halmatov, Veyis and Ateş (2013). The scale is in 5-item Likert type consisting of a total of 9 items. A rise in the score from the scale indicates that the level of individual's school burnout also rises. The scale has three sub-dimensions that measure 'emotional burnout' (4 items), 'depersonalization' (3 items) and 'low success expectation' ( 2 items), and a total score can be obtained from the scale. The scale accounts for $66.85 \%$ of the total variance. The overall internal consistency coefficient of SBS is .75 (Seçer et al., 2013).

To use the SBS within the scope of this study, reliability and validity studies were carried out first. For reliability study, the Cronbach's alpha consistency coefficient of the scale was calculated and found to be .91. CFA was performed to test the structure validity of the scale, and it was found that fit indices were significant $\left(X^{2}=1305.81, d f=524, p=.00, X^{2} / d f=2.49, R M S E A=.05, S R M R=.06, C F I=.95, N N F I=.94\right)$. Considering these values, it can be said that the scale is reliable and valid enough to be used in research (Kline, 2014).

School Attachment Scale for Adolescents (SASA): SASA was developed by Hill and Werner (2006) to assess children and adolescents' levels of school attachment. Adaptation of the scale into Turkish culture was made by Savi-Çakar (2011a). The scale is in 5-item Likert type consisting of a total of 14 items. A rise in the score from the scale indicates that individual has high level of school attachment. The scale has three sub-dimensions that measure 'school attachment' (5 items), 'teacher attachment' (5 items) and 'friend attachment' ( 4 items), and a total score can be obtained from the scale. The scale explains $58.69 \%$ of the total variant. The overall internal consistency coefficient of SASA is .84 (SaviÇakar, 2011a).

To use ASAS within the scope of this study, reliability and validity studies were carried out first. For reliability study, the Cronbach's alpha consistency coefficient of the scale was calculated and found to be .91. CFA was performed to test the structure validity of the scale, and it was found that fit indices were significant $\left(X^{2}=1020.54, \mathrm{sd}=425, \mathrm{p}=.00, \mathrm{X}^{2} / \mathrm{sd}=2.40, \mathrm{RMSEA}=.06, \mathrm{SRMR}=.06, \mathrm{CFI}=.92, \mathrm{NNFI}=.90\right)$. Considering these values, it can be said that the scale is reliable and valid enough to be used in research (Kline, 2014).

\section{Data Collection}

During the data collection process, researchers entered separately the schools in the sample and each class where the data would be collected, and students were given necessary explanations about the purpose and content of the research and scales. Signed consent forms were obtained from participants who volunteered to participate in the research. The scales were then filled in by students. Application lasted an average of 30 minutes. Completed scales are examined and scales that were not fully filled by students were not included in the study. 


\section{Data Analysis}

To perform statistical operations on the data, the data collected were first transferred to the SPSS 20.0 program. Accuracy was then checked in the data set, and all values were found to be within possible limits (Tabachnick, Fidell, \& Ullman, 2007). In addition, reverse-rated items were corrected; the data set was made ready for the lost data review. Lost data ratio in the data set was then examined, and it was found to be less than $5 \%$. It was checked to see if the lost data pattern was randomly distributed, the result of the Little's MCAR test was as significant as expected ( $p=.19>.05)$, and it was understood that the lost data distributed randomly (Little, 1988). Due to the fact that the total lost data ratio remains below $5 \%$ and the random dissolution of the data set, loss value assignment was applied to the lost data using Expectation Maximization (EM) (Tabachnick et al., 2007).

A single variable and multivariate extreme value review were conducted to detect extreme values in the data set. $Z$ test was applied to examine single-variable end value, and the $z$ score was taken between -4.00 and +4.00 as a reference value due to the sample size of more than 100 (Mertler \& Vannatta, 2005). No data have been found outside the range of standardized $z$ score -4.00 and +4.00 . Mahalonobis distance coefficient was then tested for multivariable end value analysis, but no data expressing end value were found (Tabachnick et al., 2007).

Coefficients of kurtosis and skewness were reviewed to test whether each variable provided the assumption of normality. For each of the variables, the reference value range of the kurtosis and skewness was observed between -1.00 and +1.00 . In this context, it can be said that the data is distributed normally (Çokluk, Şekercioğlu, \& Büyüköztürk, 2014).

Simple (binary) correlations between variables were reviewed to check for multiple connection problems in the data set. After the analysis, the binary correlation values between the variables were all lower than .90 (Çokluk et al., 2014). In addition, VIF and Cl values were analyzed to determine whether there were multiple connectivity problems in the data set; it was observed that VIF values for all items were less than 10 (Webster, 1992; cited by Albayrak, 2005), and Cl values were less than 30 (Gujarati, 1995; cited by Albayrak, 2005). In this context, it can be said that there is no multi-link problem between variables.

After the data were prepared for analysis, reliance and validity studies were carried out primarily to ensure that the Risky Behaviors Scale, Teacher Emotional Abuse Scale, School Burnout Scale and School Connection Scale for Adolescents could be used within the scope of the study. Cronbach's alpha internal consistency coefficient was performed to scales for testing reliability values; CFA was performed using the LISREL 8.7 program to test validity values. Obtained values show that scales are reliable and valid enough to be used in research. These values are presented in the section of the research on data collection tools.

It was determined that the data met the parametric properties required for regression analysis. To find answers to research questions in this context: Pearson Correlation Coefficient Analysis was used to determine the relationship between variables; Multiple Linear Regression Analysis was used to understand the extent to which teacher abuse, school burnout and school attachment predicted adolescents' risky behaviors. Levene Test was carried out to test whether the data provided the assumption of homogeneity, and it was concluded that the assumption of homogeneity was provided $(p<.51)$. On top of this, independent samples t-test and one-way variance analysis (ANOVA) were used for analysis of differences (Büyüköztürk, 2014). To test the source of differences, the distributions of sample in categories were observed; those who were suitable for Tukey or Hochberg's GT2 tests were used (Field, 2005). In addition, Cohen's d (Cohen, 1988) one-way variance analysis and Omega square (Kirk, 1996) effect size calculation formulas were used, and level of meaningfulness was taken as .05. 


\section{Findings}

Multiple linear regression analysis was carried out to reveal the extent to which teacher abuse, school burnout and school attachment predicted adolescents' risky behaviors. The binary correlation coefficients between dependent and independent variables were calculated to determine whether there were multiple connections between dependent and independent variables before regression analysis was carried out, the results are shown in Table 3.

Table 3.

Inter-Variable Pearson Product-Moment Correlation Coefficients.

\begin{tabular}{|c|c|c|c|c|c|c|}
\hline Variables & $x$ & $\mathbf{S}$ & 1 & 2 & 3 & 4 \\
\hline Risky Behaviors & 78.90 & 24.81 & - & & & \\
\hline Teacher Abuse & 48.37 & 12.34 & $.51 * *$ & - & & \\
\hline School Burnout & 26.71 & 9.94 & $.30 * *$ & $.34 * *$ & - & \\
\hline School Attachment & 48.37 & 12.34 & $-.37 * *$ & $-.40 * *$ & $-.45^{* *}$ & - \\
\hline
\end{tabular}

$* * p<.01$

According to Table 3, the average risky behavior of the participants was 78.90 and the standard deviation was 24.81. In addition, there is a positive oriented significant relationship between adolescents' levels of risky behavior and teacher abuse $(r=.51, p<.01)$ and school burnout $(r=.30, p<.01)$; and there is a negative-oriented significant relationship between their risky behaviors and their levels of school attachment $(r=-.37, p<.01)$. These relationships are not at the level that would create a multi-link problem in the model being constructed (which is smaller than .90); it is also understood from the analysis for the regression assumption given in the analysis section of the data (Çokluk et al., 2014). Furthermore, examining the correlation coefficients obtained, a medium level of relationship $(.30<r<.70)$ is observed between adolescents' risky behaviors and teacher abuse, school burnout and school attachment levels (Büyüköztürk, 2014).

The results obtained from a multi-linear regression analysis to determine whether the levels of teacher abuse, school burnout, and school attachment significantly predict adolescents' risky behaviors are given in Table 4.

Table 4.

Multiple Linear Regression Analysis Results on Teacher Abuse, School Burnout and School Attachment Levels as Predictors of Risky Behaviors.

\begin{tabular}{|c|c|c|c|c|c|c|c|c|c|}
\hline Variables & $\mathbf{R}$ & $\mathbf{R}^{2}$ & $\mathbf{R}_{c h}^{2}$ & $\mathbf{F}$ & df & B & $\beta$ & $\mathbf{t}$ & $\mathbf{p}$ \\
\hline Constant & .55 & .31 & .30 & $64.23 * *$ & $3 / 442$ & 67.11 & & $6.82 * *$ & .00 \\
\hline Teacher Abuse & & & & & & .12 & .09 & $.18^{* *}$ & .00 \\
\hline School Burnout & & & & & & .13 & .10 & $1.83^{* *}$ & .00 \\
\hline School Attachment & & & & & & -.22 & -.31 & $-2.55^{* *}$ & .00 \\
\hline
\end{tabular}

$* * \mathrm{p}<.01$

According to the results of the multi-linear regression analysis seen in Table 4, teacher abuse, school burnout and school attachment variable, the risky behavior scores of adolescents are significantly procedural and the model constructed for regression is significant $\left(R=.55, R^{2}=.31, F_{(3,442)}=64.23, p<.01\right)$. All these variables specified in the edited regression model have a great effect on the risky behaviors of adolescents $\left(\mathrm{R}^{2}>\right.$.26) (Cohen, 1988). In addition, teacher abuse, school burnout and school attachment variables describe $31 \%$ of adolescents' risky behaviors. 
According to the standardized regression coefficient $(\beta)$, the relative order of importance of predictive variables on adolescents' risky behavior levels is as follows; school connection $(\beta=-.31, t=-$ $2.55)$, school burnout $(\beta=.10, t=1.83)$ and teacher abuse $(\beta=.09, t=.18)$.

Examining t-test results for the significance of regression coefficients: It is observed that teacher abuse $(t=.18, p<.01)$ and school burnout $(t=1.83, p<.01)$ variables are positive predictors of adolescents' risky behaviors while school attachment $(t=-2.55, p<.01)$ is negative predictor.

Given these results, it can be said that adolescents' levels of risky behavior will increase with an increase in their scores from school burnout and teacher abuse variables; however, the increase in points in school attachment variable will reduce their risky behavior.

Unrelated samples t-test was carried out to examine whether the difference between adolescents' risky behavior scores as per gender was significant, and the results are presented in Table 5.

Table 5.

Independent Samples T-Test Results for The Examination of Adolescents' Risky Behavior Scores as per Gender.

\begin{tabular}{|c|c|c|c|c|c|c|c|c|}
\hline & Gender & $\mathbf{n}$ & $\bar{x}$ & $\mathbf{S}$ & df & $\mathbf{t}$ & \multicolumn{2}{|c|}{ p Cohen's d } \\
\hline \multirow{2}{*}{$\begin{array}{l}\text { Total Risky } \\
\text { Behaviors }\end{array}$} & Female & 235 & 75.31 & 23.19 & 444 & $-.3 .26 * *$ & .00 & .61 \\
\hline & Male & 211 & 82.90 & 25.96 & & & & \\
\hline \multirow[t]{2}{*}{ Antisocial Behavior } & Female & 235 & 15.24 & 6.61 & 444 & $-3.06 * *$ & .00 & .55 \\
\hline & Male & 211 & 17.12 & 6.30 & & & & \\
\hline \multirow[t]{2}{*}{ Alcohol Abuse } & Female & 235 & 10.60 & 6.15 & 444 & $-3.18 * *$ & .00 & .57 \\
\hline & Male & 211 & 12.67 & 7.54 & & & & \\
\hline \multirow[t]{2}{*}{ Smoking } & Female & 235 & 11.54 & 5.54 & 444 & $-1.91^{*}$ & .04 & .51 \\
\hline & Male & 211 & 12.59 & 6.07 & & & & \\
\hline \multirow[t]{2}{*}{ Suicidal Tendencies } & Female & 235 & 14.59 & 4.72 & 444 & -.57 & .56 & .04 \\
\hline & Male & 211 & 14.86 & 5.12 & & & & \\
\hline \multirow[t]{2}{*}{ Eating Habits } & Female & 235 & 12.34 & 5.48 & 444 & $-3.12 * *$ & .00 & .58 \\
\hline & Male & 211 & 13.68 & 6.28 & & & & \\
\hline \multirow[t]{2}{*}{ School Dropout } & Female & 235 & 10.88 & 5.56 & 444 & $-4.89 * *$ & .00 & .64 \\
\hline & Male & 211 & 13.81 & 7.08 & & & & \\
\hline
\end{tabular}

$* * p<.01, * p<.05$

As can be seen in Table 5, total risky behavior scores of male and female adolescents $\left(\mathrm{t}_{(444)}=-3.26\right.$, $p<.01, d=.61)$ varied significantly. Considering sub-dimensions of adolescents' risky behavior; it is observed that boys' and girls' scores from antisocial behaviors $\left(\mathrm{t}_{(444)}=-3.06, \mathrm{p}<.01, d=.55\right)$, alcohol abuse $\left(\mathrm{t}_{(444)}=-3.18, \mathrm{p}<.01, d=.57\right)$, smoking $\left(\mathrm{t}_{(444)}=-1.91, \mathrm{p}<.05, d=.51\right)$, eating habits $\left(\mathrm{t}_{(444)}=-3.12, \mathrm{p}<.01, d=.58\right)$ and school dropout $\left(\mathrm{t}_{(444)}=-4.89, \mathrm{p}<.01, d=.64\right)$ fields varied significantly. In other words, it can be seen that average total risky behaviors of male adolescents, their antisocial behaviors, alcohol abuse, smoking, eating habits and school dropout is higher than that of female adolescents. However, when Table 5 was examined, it was determined that the suicidal tendencies scores of male and female adolescents $\left(\mathrm{t}_{(444)}=-.57, \mathrm{p}>.05\right)$ did not vary significantly. In addition, as shown in Table 5, the effect size of gender on adolescents' total risk behavior $(d=.61)$, antisocial behavior $(d=.55)$, alcohol abuse $(d=.57)$, smoking $(d=.51)$, eating habits $(d=.58)$ and school leaver $(d=.64)$ score averages were moderate (Cohen, 1988).

A one-way variance analysis was carried out to determine whether the difference between adolescents' grade levels and risky behavior scores was significant, and the results are shown in Table 6. 
Table 6.

One-Way Variance Analysis Results for Examining Risky Behavior Scores by Adolescents' Grade Levels.

\begin{tabular}{|c|c|c|c|c|c|c|c|c|}
\hline \multirow{2}{*}{ Total Risky } & \multirow{2}{*}{$\begin{array}{l}\text { Grade Level } \\
\text { 9th grade }(\mathrm{A})\end{array}$} & \multirow{2}{*}{$\begin{array}{r}\mathbf{n} \\
121\end{array}$} & \multirow{2}{*}{$\begin{array}{r}\bar{x} \\
75.75\end{array}$} & \multirow{2}{*}{$\begin{array}{r}S \\
23.26\end{array}$} & \multirow{2}{*}{$\begin{array}{r}\mathbf{F} \\
1.73^{*}\end{array}$} & \multicolumn{2}{|c|}{ pDifference } & \multirow{2}{*}{$\frac{\Omega^{2}}{.08}$} \\
\hline & & & & & & .04 & $A-D$ & \\
\hline \multirow{3}{*}{ Behaviors } & 10th grade $(\mathrm{B})$ & 102 & 78.42 & 23.42 & & & & \\
\hline & 11 th grade $(\mathrm{C})$ & 105 & 80.39 & 24.78 & & & & \\
\hline & 12th grade (D) & 118 & 82.13 & 27.09 & & & & \\
\hline Antisocial & 9th grade $(A)$ & 121 & 15.49 & 6.31 & .86 & .46 & None & .01 \\
\hline \multirow[t]{3}{*}{ Behavior } & 10th grade $(\mathrm{B})$ & 102 & 16.38 & 6.69 & & & & \\
\hline & 11 th grade $(\mathrm{C})$ & 105 & 16.63 & 6.33 & & & & \\
\hline & 12th grade (D) & 118 & 16.46 & 6.89 & & & & \\
\hline \multirow[t]{4}{*}{ Alcohol Abuse } & 9th grade $(A)$ & 121 & 10.63 & 6.48 & $3.49 *$ & .01 & $A-D$ & .11 \\
\hline & 10th grade $(\mathrm{B})$ & 102 & 10.57 & 6.47 & & & & \\
\hline & 11th grade $(\mathrm{C})$ & 105 & 11.88 & 7.00 & & & & \\
\hline & 12th grade (D) & 118 & 13.06 & 7.37 & & & & \\
\hline \multirow[t]{4}{*}{ Smoking } & 9th grade $(A)$ & 121 & 11.09 & 5.24 & $4.43 * *$ & .00 & $A-D$ & .12 \\
\hline & 10th grade (B) & 102 & 11.12 & 5.43 & & & & \\
\hline & 11th grade $(\mathrm{C})$ & 105 & 12.47 & 5.86 & & & & \\
\hline & 12th grade (D) & 118 & 13.37 & 6.39 & & & & \\
\hline Suicidal & 9th grade $(A)$ & 121 & 14.87 & 4.45 & 1.18 & .31 & None & .01 \\
\hline \multirow[t]{3}{*}{ Tendencies } & 10th grade $(\mathrm{B})$ & 102 & 15.64 & 3.98 & & & & \\
\hline & 11th grade $(\mathrm{C})$ & 105 & 14.19 & 4.81 & & & & \\
\hline & 12th grade (D) & 118 & 14.50 & 5.84 & & & & \\
\hline \multirow[t]{4}{*}{ Eating Habits } & 9th grade $(A)$ & 121 & 12.51 & 6.26 & $3.26^{*}$ & .02 & $A-D$ & .10 \\
\hline & 10th grade (B) & 102 & 13.40 & 6.45 & & & & \\
\hline & 11th grade $(\mathrm{C})$ & 105 & 13.65 & 7.41 & & & & \\
\hline & 12th grade (D) & 118 & 13.78 & 7.88 & & & & \\
\hline School & 9th grade $(A)$ & 121 & 11.81 & 6.48 & .82 & .48 & None & .00 \\
\hline \multirow[t]{3}{*}{ Dropout } & 10th grade $(B)$ & 102 & 11.73 & 5.89 & & & & \\
\hline & 11th grade $(\mathrm{C})$ & 105 & 12.79 & 6.60 & & & & \\
\hline & 12th grade $(D)$ & 118 & 12.72 & 6.68 & & & & \\
\hline
\end{tabular}

$* * p<.01, * p<.05$

As shown in Table 6, the difference between the class levels of adolescents and the total risky behavior scores is statistically significant $\left(F_{(3,442)}=1.73, p<.05, \Omega^{2}=.08\right)$. Accordingly, it can be said that 12th graders exhibit more risky behaviors than 9th graders. Examining sub-dimensions of adolescents' risky behaviors, it can be seen that adolescents' scores in alcohol abuse $\left(F_{(3,442)}=3.49, p<.05, \Omega^{2}=.11\right)$, smoking $\left(F_{(3,442)}=4.43, p<.01, \Omega^{2}=.12\right)$ and nutrition habits $\left(F_{(3,442)}=3.26, p<.05, \Omega^{2}=.10\right)$ vary significantly as per their grade levels. However, it is observed that adolescents' scores from antisocial behaviors $\left(F_{(3,442)}=.84, p>.05, \Omega^{2}=.01\right)$, suicidal tendency $\left(F_{(3,442)}=1.18, p>.05, \Omega^{2}=.01\right)$ and school dropout $\left(F_{(3,442)}=.82, p>.05, \Omega^{2}=.00\right)$ do not differ significantly depending on grade levels. It is also understood that class levels are moderate in the effect size of adolescents' points averages from total risky behavior $\left(\Omega^{2}=.08\right)$, alcohol use $\left(\Omega^{2}=.11\right)$, smoking $\left(\Omega^{2}=.12\right)$ and eating habits $\left(\Omega^{2}=.10\right)$ (Kirk, 1996).

A one-way variance analysis was carried out to determine whether the difference between adolescents' academic averages and risky behavior scores was significant, and the results are submitted in Table 7. As shown in Table 7, the difference between the class levels of adolescents and the total risky behavior scores is statistically significant $\left(F_{(4,441)}=4.67, p<.01, \Omega^{2}=.13\right)$. Accordingly, students with an academic average of 49 and below exhibit more risky behaviors than students with an academic average of 85 or higher. Considering sub-dimensions of adolescents' risky behavior; it is observed that boys' and girls' scores from antisocial behaviors $\left(F_{(4,441)}=3.25, p<.05, \Omega^{2}=.10\right)$, alcohol abuse $\left(F_{(4,441)}=4.00, p<.01\right.$, $\left.\Omega^{2}=.11\right)$, smoking $\left(F_{(4,441)}=3.23, p<.05, \Omega^{2}=.09\right)$, eating habits $\left(F_{(4,441)}=3.24, p<.01, \Omega^{2}=.10\right)$ and school 
dropout $\left(F_{(4,441)}=4.60, p<.01, \Omega^{2}=.13\right)$ fields varied significantly. However, it can be said that adolescents' scores form suicidal tendencies $\left(F_{(4,441)}=.57, p>.05, \Omega^{2}=.00\right)$ do not differ significantly according to their academic average. In addition, the effect size of gender on adolescents' total risky behavior $\left(\Omega^{2}=.13\right)$, antisocial behavior $\left(\Omega^{2}=.10\right)$, alcohol abuse $\left(\Omega^{2}=.11\right)$, smoking $\left(\Omega^{2}=.09\right)$, eating habits $\left(\Omega^{2}=.10\right)$ and school leaver $\left(\Omega^{2}=.13\right)$ score averages were moderate (Kirk, 1996).

Table 7.

One-Way Variance Analysis Results for Examining Risky Behavior Scores by Adolescents' Academic Averages.

\begin{tabular}{|c|c|c|c|c|c|c|c|c|}
\hline & Grade Point Average & $\mathbf{n}$ & $\bar{x}$ & $\mathbf{S}$ & $\mathbf{F}$ & $p$ & Difference & $\Omega^{2}$ \\
\hline Total Risky & 49 and lower $(\mathrm{A})$ & 53 & 85.36 & 26.67 & $4.67^{* *}$ & .00 & $A-D$ & .13 \\
\hline \multirow[t]{3}{*}{ Behaviors } & Between 50-69 (B) & 168 & 83.47 & 25.32 & & & & \\
\hline & Between 70-84 (C) & 161 & 74.34 & 22.86 & & & & \\
\hline & 85 and above (D) & 64 & 73.32 & 23.84 & & & & \\
\hline Antisocial & 49 and lower $(A)$ & 53 & 18.00 & 7.26 & $3.25 *$ & .01 & $A-D$ & .10 \\
\hline \multirow[t]{3}{*}{ Behavior } & Between 50-69 (B) & 168 & 16.95 & 6.63 & & & & \\
\hline & Between 70-84 (C) & 161 & 15.05 & 6.03 & & & & \\
\hline & 85 and above (D) & 64 & 15.21 & 6.41 & & & & \\
\hline \multirow[t]{4}{*}{ Alcohol Abuse } & 49 and lower $(A)$ & 53 & 13.07 & 7.22 & $4.00^{* *}$ & .00 & $A-D$ & .11 \\
\hline & Between 50-69 (B) & 168 & 12.81 & 7.24 & & & & \\
\hline & Between 70-84 (C) & 161 & 10.50 & 6.57 & & & & \\
\hline & 85 and above (D) & 64 & 9.90 & 5.91 & & & & \\
\hline \multirow[t]{4}{*}{ Smoking } & 49 and lower $(A)$ & 53 & 12.51 & 6.19 & $3.23^{*}$ & .01 & $A-D$ & .09 \\
\hline & Between 50-69 (B) & 168 & 11.88 & 6.22 & & & & \\
\hline & Between 70-84 (C) & 161 & 11.32 & 5.41 & & & & \\
\hline & 85 and above (D) & 64 & 10.60 & 4.87 & & & & \\
\hline Suicidal & 49 and lower $(A)$ & 53 & 15.44 & 4.97 & .57 & .68 & None & .00 \\
\hline \multirow[t]{3}{*}{ Tendencies } & Between 50-69 (B) & 168 & 14.80 & 5.38 & & & & \\
\hline & Between 70-84 (C) & 161 & 14.64 & 4.59 & & & & \\
\hline & 85 and above (D) & 64 & 14.12 & 4.39 & & & & \\
\hline \multirow[t]{4}{*}{ Eating Habits } & 49 and lower $(A)$ & 53 & 15.18 & 7.01 & $3.24 * *$ & .00 & $A-D$ & .10 \\
\hline & Between 50-69 (B) & 168 & 14.72 & 6.86 & & & & \\
\hline & Between 70-84 (C) & 161 & 12.46 & 6.45 & & & & \\
\hline & 85 and above (D) & 64 & 11.91 & 5.96 & & & & \\
\hline \multirow[t]{4}{*}{ School Dropout } & 49 and lower $(A)$ & 53 & 13.81 & 6.71 & $4.60 * *$ & .00 & $A-D$ & .13 \\
\hline & Between 50-69 (B) & 168 & 13.48 & 6.74 & & & & \\
\hline & Between 70-84 (C) & 161 & 10.73 & 5.44 & & & & \\
\hline & 85 and above (D) & 64 & 11.79 & 7.28 & & & & \\
\hline
\end{tabular}

$* * \mathrm{p}<.01, * \mathrm{p}<.05$

A one-way variance analysis was carried out to determine whether the difference between adolescents' risky behavior scores varied significantly as per their perceived socioeconomic levels, and the results were shown in Table 8 . As seen in Table 8 , the difference between adolescents' risky behavior scores and their perceived socioeconomic status was statistically significant $\left(F_{(2,443)}=14.36\right.$, $\left.p<.01, \Omega^{2}=.13\right)$. Accordingly, it can be said that adolescents, who perceive the socioeconomic level as low, exhibit more risky behaviors than adolescents who perceive their socioeconomic level as high. Considering sub-dimensions of adolescents' risky behavior; it is observed that boys' and girls' scores from antisocial behaviors $\left(F_{(2,443)}=6.20, p<.01, \Omega^{2}=.12\right)$, alcohol abuse $\left(F_{(2,443)}=7.47, p<.01, \Omega^{2}=.13\right)$, smoking $\left(F_{(2,443)}=11.81, p<.01, \Omega^{2}=.13\right)$, suicidal tendency $\left(F_{(2,443)}=3.29, p<.05, \Omega^{2}=.10\right)$, eating habits $\left(F_{(2,443)}=6.21, p<.01, \Omega^{2}=.12\right)$ and school dropout $\left(F_{(2,443)}=11.63, p<.01, \Omega^{2}=.13\right)$ fields varied significantly. In addition, the effect size of perceived socioeconomic level on adolescents' total risky behavior $\left(\Omega^{2}=.13\right)$, antisocial behavior $\left(\Omega^{2}=.12\right)$, alcohol abuse $\left(\Omega^{2}=.13\right)$, smoking $\left(\Omega^{2}=.13\right)$, suicidal tendencies $\left(\Omega^{2}=.10\right)$, eating habits $\left(\Omega^{2}=.12\right)$ and school leaver $\left(\Omega^{2}=.13\right)$ score averages were moderate (Kirk, 1996). 
Table 8.

One-Way Variance Analysis Results for Examining Risky Behavior Scores by Adolescents' Perceived Socioeconomic Levels.

\begin{tabular}{|c|c|c|c|c|c|c|c|c|}
\hline \multirow[b]{2}{*}{ Total Risky } & \multirow{2}{*}{$\begin{array}{l}\text { SES } \\
\text { Low (A) }\end{array}$} & \multirow{2}{*}{$\begin{array}{r}\mathbf{n} \\
89\end{array}$} & \multirow{2}{*}{$\frac{\bar{x}}{104.31}$} & \multirow{2}{*}{$\begin{array}{r}\text { S } \\
28.85\end{array}$} & \multirow{2}{*}{$\begin{array}{r}\mathbf{F} \\
14.36^{* *}\end{array}$} & \multicolumn{2}{|c|}{ p Difference } & \multirow{2}{*}{$\frac{\boldsymbol{\Omega}^{\mathbf{2}}}{.13}$} \\
\hline & & & & & & .00 & $A-B$ & \\
\hline \multirow[t]{2}{*}{ Behaviors } & Moderate (B) & 176 & 80.89 & 26.08 & & & $B-C$ & \\
\hline & Good (C) & 181 & 74.87 & 21.61 & & & $A-C$ & \\
\hline Antisocial & Low $(A)$ & 89 & 20.63 & 7.38 & $6.20 * *$ & .00 & $A-B$ & .12 \\
\hline \multirow[t]{2}{*}{ Behavior } & Moderate (B) & 176 & 16.47 & 6.58 & & & $B-C$ & \\
\hline & Good (C) & 181 & 15.42 & 6.25 & & & $A-C$ & \\
\hline Alcohol & $\operatorname{Low}(A)$ & 89 & 16.89 & 8.43 & $7.47^{* *}$ & .00 & $A-B$ & .13 \\
\hline \multirow[t]{2}{*}{ Abuse } & Moderate (B) & 176 & 11.93 & 7.47 & & & $B-C$ & \\
\hline & Good (C) & 181 & 10.80 & 5.97 & & & $A-C$ & \\
\hline \multirow[t]{3}{*}{ Smoking } & Low $(A)$ & 89 & 17.63 & 6.91 & $11.81^{* *}$ & .00 & $A-B$ & .13 \\
\hline & Moderate (B) & 176 & 12.38 & 6.10 & & & $B-C$ & \\
\hline & Good (C) & 181 & 10.23 & 5.12 & & & $A-C$ & \\
\hline Suicidal & $\operatorname{Low}(\mathrm{A})$ & 89 & 17.31 & 4.89 & $3.29 *$ & .03 & $A-B$ & .10 \\
\hline \multirow[t]{2}{*}{ Tendencies } & Moderate (B) & 176 & 14.84 & 4.89 & & & $B-C$ & \\
\hline & $\operatorname{Good}(C)$ & 181 & 13.38 & 4.88 & & & $A-C$ & \\
\hline Eating & $\operatorname{Low}(\mathrm{A})$ & 89 & 17.84 & 7.91 & $6.21^{* *}$ & .00 & $A-B$ & .12 \\
\hline \multirow[t]{2}{*}{ Habits } & Moderate (B) & 176 & 13.45 & 6.57 & & & $B-C$ & \\
\hline & Good (C) & 181 & 11.94 & 5.98 & & & $A-C$ & \\
\hline School & $\operatorname{Low}(\mathrm{A})$ & 89 & 18.63 & 7.54 & $11.63^{* *}$ & .00 & $A-B$ & .13 \\
\hline \multirow[t]{2}{*}{ Dropout } & Moderate (B) & 176 & 12.56 & 6.40 & & & $B-C$ & \\
\hline & Good (C) & 181 & 11.45 & 6.16 & & & $A-C$ & \\
\hline
\end{tabular}

$* * \mathrm{p}<.01,{ }^{*} \mathrm{p}<.05$

A one-way variance analysis was carried out to determine whether the difference between adolescents' family structures and risky behavior scores was significant, and the results are shown in Table 9. As shown in Table 9, the difference between adolescents' family structures and their total risky behavior scores is statistically significant $\left(F_{(2,443)}=9.85, p<.01, \Omega^{2}=.12\right)$. Accordingly, adolescents whose parents are "separate" and "mother and/or father are dead" are more at risk than adolescents whose parents are together. Considering sub-dimensions of adolescents' risky behaviors; it is observed that boys' and girls' scores from antisocial behaviors $\left(F_{(2,443)}=5.03, p<.01, \Omega^{2}=.10\right)$, alcohol abuse $\left(F_{(2,443)}=6.24\right.$, $\left.p<.01, \Omega^{2}=.11\right)$, smoking $\left(F_{(2,443)}=10.75, p<.01, \Omega^{2}=.13\right)$, suicidal tendencies $\left(F_{(2,443)}=7.01, p<.01, \Omega^{2}=.12\right)$, eating habits $\left(F_{(2,443)}=6.45, p<.01, \Omega^{2}=.11\right)$ and school dropout $\left(F_{(2,443)}=4.82, p<.01, \Omega^{2}=.09\right)$ fields varied significantly. It is also understood that the size of impact of perceived socioeconomic level on total risky behaviors $\left(\Omega^{2}=.12\right)$, antisocial behaviors $\left(\Omega^{2}=.10\right)$, alcohol abuse $\left(\Omega^{2}=.11\right)$, smoking $\left(\Omega^{2}=.13\right)$, suicidal tendency $\left(\Omega^{2}=.12\right)$, nutrition habits $\left(\Omega^{2}=.11\right)$ and school dropout $\left(\Omega^{2}=.09\right)$ score averages is moderate (Kirk, 1996).

\section{Conclusion and Discussion}

When the findings of the study were taken in order of sub-problems, the first variables of teacher abuse and school burnout were a positive-oriented predictor on adolescents' risky behaviors whereas school attachment was found to be a negatively significant predictor.

Examining some of the studies in the literature supporting the study's finding that there is a positively significant relationship between adolescents' risky behavior and teacher abuse, it is observed that students who perceive a high level of abuse from their teachers in relation to cases of abuse in schools have tendency to exhibit high levels of risky behaviors (Cansı, 2019). In addition, there is a relationship between teacher abuse and problem behaviors such as rejecting school, negative perception of oneself and others (King \& Janson, 2011), aggression and increased impulsivity 
(McEachern, Aluede, \& Kenny, 2008). In general, given the negative effects of abuse, it has been found that there is an increased orientation to risky behaviors as the life of abuse increases (Arnow, 2004; Chen \& Liao, 2005; Fry et al. 2012); and abuse from many psychological problems such as depression, suicide, alcohol abuse, substance abuse and anxiety disorders is a risk factor (Young \& Widom, 2014). These results are seen to be in line with the findings of this research.

Table 9.

One-Way Variance Analysis Results for Examining Risky Behavior Scores by Adolescents' Family Structures.

\begin{tabular}{|c|c|c|c|c|c|c|c|c|}
\hline \multirow{2}{*}{$\bar{T} \overline{\text { Total Risky }}$} & \multirow{2}{*}{$\begin{array}{l}\text { Family Structure } \\
\text { Parents together (A) }\end{array}$} & \multirow{2}{*}{$\begin{array}{r}\mathbf{n} \\
206\end{array}$} & \multirow{2}{*}{\begin{tabular}{r|}
$\bar{x}$ \\
77.11
\end{tabular}} & \multirow{2}{*}{$\begin{array}{r}S \\
24.03\end{array}$} & \multirow{2}{*}{$\begin{array}{r}\mathbf{F} \\
9.85 * *\end{array}$} & \multicolumn{2}{|c|}{ p Difference } & \multirow{2}{*}{$\begin{array}{l}\Omega^{2} \\
.12\end{array}$} \\
\hline & & & & & & .00 & $A-B$ & \\
\hline \multirow[t]{2}{*}{ Behaviors } & Parents separate (B) & 143 & 86.48 & 26.11 & & & $A-C$ & \\
\hline & $\begin{array}{l}\text { Mother and/or father dead } \\
\text { (C) }\end{array}$ & 97 & 100.52 & 26.57 & & & & \\
\hline Antisocial & Parents together $(A)$ & 206 & 15.88 & 6.47 & $5.03 * *$ & .00 & $A-B$ & .10 \\
\hline \multirow[t]{2}{*}{ Behavior } & Parents separate (B) & 143 & 16.46 & 6.20 & & & $A-C$ & \\
\hline & $\begin{array}{l}\text { Mother and/or father dead } \\
\text { (C) }\end{array}$ & 97 & 20.94 & 7.11 & & & & \\
\hline Alcohol & Parents together $(A)$ & 206 & 11.13 & 6.60 & $6.24 * *$ & .00 & $A-B$ & .11 \\
\hline \multirow[t]{2}{*}{ Abuse } & Parents separate (B) & 143 & 14.13 & 8.14 & & & $A-C$ & \\
\hline & $\begin{array}{l}\text { Mother and/or father dead } \\
\text { (C) }\end{array}$ & 97 & 15.23 & 8.46 & & & & \\
\hline \multirow[t]{3}{*}{ Smoking } & Parents together $(A)$ & 206 & 11.58 & 5.49 & $10.75^{* *}$ & .00 & $A-B$ & .13 \\
\hline & Parents separate (B) & 143 & 14.23 & 7.05 & & & $A-C$ & \\
\hline & $\begin{array}{l}\text { Mother and/or father dead } \\
\text { (C) }\end{array}$ & 97 & 16.94 & 6.26 & & & & \\
\hline Suicidal & Parents together $(A)$ & 206 & 14.39 & 4.87 & $7.01^{* *}$ & .00 & $A-B$ & .12 \\
\hline Tendencies & sParents separate (B) & 143 & 16.46 & 5.01 & & & $A-C$ & \\
\hline & $\begin{array}{l}\text { Mother and/or father dead } \\
\text { (C) }\end{array}$ & 97 & 17.76 & 3.57 & & & & \\
\hline Eating & Parents together $(A)$ & 206 & 11.54 & 5.56 & $6.45^{* *}$ & .00 & $A-B$ & .11 \\
\hline \multirow[t]{2}{*}{ Habits } & Parents separate (B) & 143 & 13.78 & 6.98 & & & $A-C$ & \\
\hline & $\begin{array}{l}\text { Mother and/or father dead } \\
\text { (C) }\end{array}$ & 97 & 16.27 & 7.14 & & & & \\
\hline School & Parents together $(A)$ & 206 & 11.98 & 6.41 & $4.82 * *$ & .00 & $A-B$ & .09 \\
\hline \multirow[t]{2}{*}{ Dropout } & Parents separate (B) & 143 & 13.13 & 6.37 & & & $A-C$ & \\
\hline & $\begin{array}{l}\text { Mother and/or father dead } \\
\text { (C) }\end{array}$ & 97 & 16.70 & 6.99 & & & & \\
\hline
\end{tabular}

Exposure to abuse in adolescents involves extremely negative experiences of physical, mental, emotional or sexual dimensions. These experiences, even if involuntarily, come to the adolescent's mind from time to time, causing a series of negative and deep emotions to occur. Adolescents trying to cope with this emotional pain and distress, high levels of anxiety, loneliness, guilt and shame, negative perception of self-worth, feeling betrayed, anger, hatred, worthlessness and desperation can often turn to risky behaviors to get rid of these feelings (Favazza, 1992; Ögel et al., 2007). It is also emphasized that the inability to suppress and deal with feelings created by abuse and neglect increases orientation to risky behaviors in adolescents (Ögel et al., 2007). In this context, teachers have a very important position in terms of abuse experiences in adolescents. It is known that the teacher-student relationship is based on the power relationship that is inherent in abuse, and that some teachers tend to use their powers negatively on adolescents. In this respect, this finding of the research shows that students are at risk in terms of teacher abuse and risky behavior. 
The second finding in study's regression results is that school burnout significantly affects adolescents' risky behaviors in a positive significant direction. The relationship between risky behaviors in adolescents and school burnout is similarly highlighted in other studies in the literature (Salmela-Aro \& Upadyaya, 2014; Yang \& Farn, 2005). In these studies, there are problems found in students related to the negative consequences of school burnout, such as anxiety and fear (Maslach, 2003), high stress levels, depression (Salmela-Aro et al., 2009), increased impulsiveness (Luo, Wang, Zhang, Chen, \& Quan, 2016), psychological dissonance (Lee \& Lee, 2018). In addition, school burnout is seen as a major risk factor for the emergence of other risky behaviors, such as substance use, due to lower school dropouts, lower interest and motivation for classes, and increased rate of dropouts (Yang \& Farn, 2005). In addition to all these results, school burnout is negative with positive situations such as school cohesion (Choi \& Lee, 2014), self-esteem (Luo et al., 2016), achievement goals and academic coping (Shih, 2015); positively relate to negative mental processes such as irrational beliefs (Uzun \& Kemerli, 2019); positive adolescent development. Accordingly, it is thought that studies on the prevention of school burnout in schools will also contribute to the prevention of risky behaviors.

Another finding in the regression results of the study is that the level of attachment to the school significantly tires of the risky behavior of adolescents in a negative way. When the field was examined, some studies similarly found that risky behaviors decreased as school attachment increased (Catalano, Haggerty, Oesterle, Fleming, \& Hawkins, 2004; Diaz, 2005; Şimşek \& Çöplü, 2018). In these studies, high levels of school attachment are significantly associated with lower rates of adolescent quality of life (Savi-Çakar, 2011b), intent to drink alcohol (Henry \& Slater, 2007), criminal and risky behavior (Rudasill et al., 2010). In addition, low levels of school attachment are associated with an increase in emotional and behavioral problems in adolescents while high levels of school attachment are associated positively with psychological robustness (Savi-Çakar, 2018). In line with these results, intervention efforts against adolescents who exhibit risky behaviors; activities aimed at increasing the level of connecting to the school can be very functional. As a matter of fact, as an important psychosocial structure, school can be considered as an important protective factor in terms of psychological and social cohesion in adolescents with emotional and cognitive attachment, as well as feeling at school, receiving support and active participation in the school environment (Jimerson, Campos, \& Greif, 2003).

Another finding of the study is that risky behaviors differred significantly depending on gender. In this context, it was determined that male adolescents had a higher total risk behavior, antisocial behavior, alcohol use, smoking, unhealthy eating habits and school dropout scores than girls. When the literature is examined, these results are similar to some research results (Akanni, Koleoso, Olashore, Adayonfo, Osundina, \& Ayilara, 2017; Brady, Song, \& Halpern-Felsher, 2008; Karayağız-Muslu \& Aygün, 2017; Şimşek \& Çöplü, 2018). In these studies, antisocial behaviors in men showed more prevalence (Akyüz, 2019; Pérez-Fuentes et al., 2011); in addition to substance abuse, school leave and general risky behaviors; alcohol and cigarettes and other substances were found to be higher than girls (Akyüz, 2019; Brady et al., 2008). In addition, averages of men are also higher in criminalness and aggression (Aydin \& Akgün, 2014); substance use and taking risks related to social position in traffic (Karahan, Sardoğan, Gençoğlu, \& Yılan, 2006). In the study conducted by Kaya, Bilgin and Singer (2012), it was also determined that unwanted behaviors such as violence, bullying and uncontrolled outbursts of anger are more common in male adolescents than girls. Considering the difference as per gender in terms of behavioral issues; it has been observed that internalization behavior problems in girls are more common in men, and externalization behavior problems are more common in boys (Savi-Çakar, 2008; Şimşek, Erol, Öztop, \& Özer-Özcan, 2008). Based on all these results, it can be said that there are different explanations for the differentiation of risky behaviors in adolescents by gender. In opinions highlighting gender roles and the impact of cultural factors (Hagan, Simpson, \& Gills, 1987); it is stated that genderrelated impositions in society reinforce roles such as passiveness in women, and independence (Dökmen, 2019), fearlessness, strength and harshness (Sancar, 2017) in men, and this may be associated with risky behavior in male adolescents. It is also emphasized that the increasing show of force and risktaking in adolescence (Gardner \& Steinberg, 2005) plays a more effective role on male adolescents than girls (Botdorf, Rosenbaum, Patrianakos, Steinberg, \& Chein, 2017). In addition to these explanations, 
biological factors that increase aggression and outward orientation in men should not be overlooked that androgen and testosterone hormone and the brain reward system may be associated with risky behaviors (Chein, Albert, O'Brien, Uckert, \& Steinberg, 2011).

On the other hand, there was no significant difference between adolescent boys and girls in terms of suicidal tendencies. The literature shows that suicidal tendencies are higher in predominantly female adolescents (Akın \& Berkem, 2012; Akyüz, 2019; Hawton, 2000; Jiang, Perry, \& Hesser, 2010; Savi-Çakar, Girgin, \& Uzun, 2020; Ulusoy, Demir, \& Baran, 2005). The study by Zhang, Lei, Song, Lu, Duan and Prochaska (2019) also found that the prevalence of suicidal thoughts was significantly higher in girls than in boys. In this context, based on the results of this research, the importance of establishing genderspecific suicide prevention targets for high-risk groups in terms of suicidal tendencies is assigned.

The finding that there was no significant difference between boys and girls in terms of the suicidal tendency obtained in this study suggests that a more comprehensive assessment of the role of gender in the suicidal process is needed. As a matter of fact, given the multidimensional and complex nature of adolescent suicides, it is not possible in this study to understand the effect of sex in the suicidal process in boys and girls. Durak-Batıgün (2008), on the other hand, emphasizes that different variables for both sexes can be exhausting in explaining the differences observed between the sexes in the area of suicidal behavior. As a matter of fact, in the study conducted by Durak-Batıgün (2008), variables such as interperson communication styles, reasons for life, despair and loneliness; it has been determined that suicide in men and women is tired at different levels. At this point, while trying to understand the suicidal process, the role of gender should be assessed in studies where different research processes are planned to understand the nature of adolescent suicides considering that other variables are also important regarding the gender roles of men and women. When all these results are evaluated in general, although the findings that risky behaviors are different by gender are weighted; as in many areas today, it is stated that the determinant of the gender factor in risky behaviors decreases and the incidence of risky behavior in girls is similar to that of boys (Tharp-Taylor, Haviland, \& D'Amico, 2009). In this context, it is thought that longitudinal studies on gender related to risky behaviors are needed.

Another finding in the study is that risky behaviors differ significantly depending on adolescents' grade levels. In this context, it was determined that 12th grade students' scores from total risky behavior, alcohol use, smoking and nutrition habits sub-dimensions were higher than students in 9th grade; however, adolescents' antisocial behavior, suicidal tendencies and school dropout scores did not differ significantly according to their grade levels. Examining the field literature, it is observed that this finding is supported by the findings of studies revealing that risky behaviors increase as the class level increases in adolescents (Öngören, Sarıefe, \& Balcı, 2017; Şimşek \& Çöplü, 2018). It is also consistent with the results of studies that found that 12th graders are older in age than 9th graders and that there is an increase in risky behaviors with age (Öngören et al., 2017). Furthermore, the prevalence of antisocial behavior sycophant increased with age and school year (Pérez-Fuentes et al., 2011), and it was determined that senior adolescents had a higher orientation to risky behaviors (Karayağız-Muslu \& Aygün, 2017). Increase in risky behaviors in adolescents as per grade level can also be descriptive in terms of assessing importance of adolescent risky behavior prevention and intervention efforts in high schools and impact of existing practices. That is because risky behaviors increasing with adolescence should take an important place in effective preventive studies from 9th grade. In this context, with the dissemination of effective prevention and intervention programs with school-based intervention studies, these problems may be greatly reduced at the 12th grade level. This result of the research may be important to show that there is a need to show whether adequate prevention and intervention work has been carried out in schools.

Another finding of the study is that risky behaviors varied significantly depending on adolescents' academic averages. In this context, it was determined that students with an academic average of 49 and below exhibited more risky behaviors than students with an academic average of 85 or higher; this difference was seen both in total risky behaviors and anti-social behaviors, alcohol use, smoking, eating habits and school dropout. Similar studies with the results of the study show increased risky behaviors 
and risk-taking behaviors as academic success ingested (Siyez, 2009); there is a negatively significant relationship between antisocial behavior and academic achievement (Girma et al., 2019). In their study, Pérez-Fuentes et al. (2011) determined that academic failure was positively related to antisocial behavior and criminal conduct. It has also been revealed that academic failure increases the risk of alcohol and smoking in adolescents (Öngören et al., 2017). Similarly, the study conducted by Akyüz (2019) also found that loss of academic achievement/loss of success is an important risk factor for showing risky behaviors; adolescents who have lost academic success for any reason have significantly higher levels of antisocial behavior, substance abuse, school dropout and general risky behavior.

While it is emphasized that low academic achievement in adolescents is associated with low selfesteem, low school attendance, anger, destructive behaviors and anti-social behaviors; low academic achievement results in low self-esteem, low levels of commitment to school, frustration, guilt and antisocial behavior (Li \& Armstrong, 2009). As a matter of fact, it is also indicated that academic failure is a harbinger of problem behavior, reduced attendance time for meaningful learning activities of failed students would mean increased aggressive behavior (Chen, Rubin, \& Li, 1997; Choi, 2007). In addition, aggressive children can develop negative relationships with teachers and peers or negative feelings about school, and as a result they may be less inclined to strive for academic studies (Arnold, 1997). These results can be assessed as a sufficient level of academic achievement for adolescents to play a protective role in the orientation of risky behaviors. Accordingly, educational guidance studies to be carried out within the scope of school psychological counseling and guidance services can contribute positively to the prevention of risky behaviors of adolescents and therefore to mental health.

In the study, it was also determined that suicidal tendency, among adolescent risky behaviors, did not significantly varied as per academic average. This result is also supported in other studies conducted in the field. Also, in Akyüz's study (2019), it was concluded that suicidal tendencies did not differ significantly according to the loss of academic achievement. On the other hand, studies examining the risk factors of adolescent suicides in the literature emphasize that academic problems are an important factor (Xing et al., 2010). One of the reasons for the suicide attempt of girls between the ages of 15 and 18 was academic failure (6.30\%) (Gül, Yürümez, \& Gül, 2017). As these results suggest, risk factors in adolescent suicide vary. It is thought that it is very important to investigate the effect of academic success on adolescent suicides in order to understand the multi-factor structure that plays a role in adolescent suicides, to make effective prevention and intervention studies. For this reason, adolescents with academic problems should be evaluated as multifaceted in terms of risky behaviors.

Another finding in the study is that risky behaviors vary significantly according to their perceived socioeconomic status in the families of adolescents. Adolescents who describe their family's socioeconomic level as low exhibit more risky behaviors than those who define their socioeconomic level as high; it was determined that both total risky behaviors and anti-social behaviors, alcohol use, smoking, suicidal tendencies, eating habits and school dropout varied significantly according to the perceived socioeconomic level. This finding is supported by some studies in the literature (Çavuş, Çavuş, \& Görpelioğlu, 2017; Wilkinson \& Marmot, 2003); as socioeconomic stress level increases in the family, so do children's problem behavior (Borghol et al., 2012). Low socioeconomic level, which is an important risk factor for adolescent risky behavior; is also a major risk factor for issues such as domestic violence, child abuse, violent domestic conflicts and substance use (Çavuş et al., 2017). As a matter of fact, in preventing adolescent risky behaviors, the economic and social structure of the family and the educational status of parents can provide a positive layer to the development of adolescents. It is also noted that high socioeconomic conditions protect adolescent from adverse environmental pressures, bad habits and risky behaviors (Greydanus \& Patel, 2003). As a matter of fact, it supports this in studies that show that as parental education level and family income level increase, orientation to risky behavior decreases (Karayağız-Muslu \& Aygün, 2017).

On the other hand, contrary to all these findings and explanations found in the field literature; it is indicated that the high economic income level of families is a risk factor in terms of risky behaviors, and risky behaviors increased in adolescents with high income families (Aras, Günay, Özan, \& Orçın, 2007; 
Elgar et al., 2013; Öngören et al., 2017). It is emphasized that increased opportunities with higher level of family's socioeconomic and sociocultural status also lead to more lack of parents' control on adolescents; in the following period, this situation leads to an increase in substance abuse, addiction to drugs and alcohol abuse, as well as risk-taking behaviors (Akca \& Selen, 2016) and anti-social behaviors (Aras et al., 2007; Çavuş et al., 2017) in adolescents. On the other hand, there are studies suggesting that risky behaviors do not vary according to family income level and parental education (Akca \& Selen, 2016). While these results reveal the importance of socioeconomic level of the family in terms of adolescents' risky behavior. Accordingly, it is seen that studies aimed at determining what kind of risky behaviors of adolescents and what kind of effect the socioeconomic structure of the family has is important.

Another finding of the study is that risky behaviors varied significantly depending on adolescents' family structure. Accordingly, adolescents whose parents are "separate" and "mother and/or father are dead" exhibit risky behaviors more than adolescents whose parents are together. It was determined that this difference emerges both in total risky behaviors and antisocial behaviors, alcohol abuse, smoking, suicidal tendencies, eating habits and school dropout. This finding can be interpreted as the fact that separated parents or parents' death is an important factor in terms of adolescent's risky behaviors; parental loss (all losses in different forms of divorce, separation, death and abandonment) has a role in tendency towards risky behaviors in adolescents by assessing this situation as loss and grief process in adolescents. While parental death is a traumatic enough experience for children to hinder the normal developmental process (Australian National University, 2020); incompatible behaviors may occur during the grief process (Humphrey, 2009). Considering the relevant studies, it is seen that there is a significant relationship between parents' living status and risky behaviors. In the literature, it was found out that adolescents with high levels of grief due to loss, they have significantly higher levels of risky behaviors, substance abuse and school dropout compared to adolescents who do not experience grief or who experience low level of grief (Akyüz, 2019). In addition, adolescents whose parents have passed away have a higher risk of smoking and suicidal tendencies (Walker \& Shaffer, 2007), risky behaviors and criminal behaviors (Akyüz, 2019). In the literature, in male adolescents who lost their parents, the use of volatile substances; smoking and substance use is expressed in girls (Zisook \& Kendler, 2007). Again, students whose parents are divorced also have a higher suicidal tendency (Öngören at al., 2017). Studies conducted on adolescents' antisocial behaviors; fragmented families or adolescents' loss of parents during childhood are noted. Parental loss, as well as divorce and family economic losses; in addition to psychosocial cohesion of adolescents, it also increases negative outcomes in many areas (Griffiths, 2003). As highlighted in the above explanations, adolescents may be unable to cope with these changes in the family structure caused by the separation of parents or the death of the parents, and may be directed towards risky behavior.

\section{Suggestions}

In light of based on the results obtained in the study, the following recommendations are presented:

- In a way to prevent risky behavior in adolescents, teachers can be trained in skills to support positive adolescent development.

- Based on the finding that school burnout will also contribute to prevention of risky behaviors in adolescents, school burnout can be prevented with school-based prevention programs.

- Psychoeducation programs may also be applied towards increasing school attachment.

- In schools, it may be useful to conduct studies aimed at identifying early warning signs of risky behavior and creating an early intervention system.

- Studies can be conducted to determine risky behavior types in adolescents according to their socioeconomic levels.

- Considering the reciprocal relationship between academic achievement and risky behaviors in adolescents, educational guidance and personal-social guidance activities can be emphasized in schools. 


\section{Limitations}

The results of this study have showed consistent and strong relationships between risky behaviors for high school student adolescents and school burnout, perceived abuse from a teacher, and attachment to school. While interpreting the findings, it should be considered that there are some limitations. First, it should be noted that due to the cross-sectional design of this study, the causal relationship between risky behaviors and other factors cannot be revealed. Second, a biased attitude was applied based on the traditional view that risky behaviors represent a problematic situation in adolescents, and the view that risky behaviors will serve a positive purpose in adolescents was ignored. Third, it may not be said that the research does not reflect adolescents living in countryside. Therefore, more research is needed about these groups to generalize the findings. 
Turkish Version

\section{Giriş}

Ergen gelişimi ve uyum süreci açısından riskli davranışların amaç ve işlevlerini tanımlamak, koruyucu ve önleyici çalışmalarla ergen ruh sağlığını güçlendirmeye odaklanmak için önemlidir. Dünyada yaşanan hızlı ve öngörülemez değişimlerin yansımaları ile birlikte ergenlerin başa çıkmak zorunda oldukları dönemsel psikososyal mücadelelerin yarattığı karmaşalar da eklenince ergenliğin çok daha zorlu bir sürece dönüşebileceği açıkça görülmektedir. Bu nedenle ergenlerde sıklıkla ortaya çıkan riskli davranışlara yönelimin nedenlerini anlamak hem ergen araştırmalarında hem de ruh sağlığı çalışmalarında önemli bir ihtiyaç olarak değerlendirilebilir.

Ergenlerin riskli davranışlarını ele alan yaklaşımlardan problem davranış teorisinde, riskli davranışlar "ergen için hayati tehlike yaratan ya da sağlığını tehdit eden, hastalık, yaralanma veya ölümle sonuçlanma ihtimali yüksek davranışlar" olarak tanımlanmaktadır. Ayrıca, riskli davranışların ergenin yaşamında bazı amaçlara hizmet ettiği ve riskli davranışlara yönelmede motivasyonun önemli olduğu vurgulanırken; ergenin problem davranışlar gösterme olasılığını artıran (risk faktörleri) ve engelleyen faktörler (koruyucu faktörler) üzerinde durulmaktadır (Jessor, 1991). Ergenlerin riskli davranışlarını ele alan sosyal öğrenme teorisine göre ise, riskli davranışların oluşumunda aile ve akranlar gibi sosyal faktörler oldukça önemlidir. Buna göre ergenlerin riskli davranışlara yöneliminde, gözlem yoluyla öğrenme, öz-yeterlik inancı, heyecan arayışı, risk alma davranışı ve algılanan akran etkisine direnme gibi faktörlere odaklanılmalıdır (Bandura, 2006). Ergenlerin riskli davranışlarını ele alan sosyal kontrol teorisinde ise Hirschi (2002), riskli davranışları ergen ve toplum arasındaki bağın azalmasıyla açıklarken; ergenlerin okul, aile ve arkadaşları ile kurduğu bağlar aracılığıyla riskli davranışlara yöneliminin azalacağını savunmaktadır. Ayrıca, ekolojik yaklaşımda Bronfenbrenner (1979), çevresel etkenlerin ergen gelişimi üzerindeki etkilerini, ebeveyn ergen arasındaki etkileşimden başlayarak kültür gibi daha uzak faktörlerinde etkisine uzanan geniş bir perspektiften ele almıştır. Bu çerçevede Bronfenbrenner (1979), riskli davranışları açıklarken ergen ve ergenin içinde bulunduğu çevre sistemleri arasındaki etkileşimlere odaklanmaktadır. Tüm bu kuramlarda da açıkça vurgulandığı gibi ergen riskli davranışlarının ortaya çıkmasında farklı etkenlerin rol oynadığı görülmektedir.

Ergenlikte riskli davranışların, tekrarlayıcı olması ve süreklilik taşıması (Ögel, Akço, Aksoy, Dönmez, Yılmazçetin, Erdoğan et al., 2007), ergenlerin riskli davranışları sonuçlarını ön görmeden gerçekleştirmesi (Siyez, 2009), aynı zamanda birden fazla riskli davranışın birlikte görülme olasılığının yüksek olması (Lindberg, Boggess, Porter, \& Williams, 2000) nedeniyle odaklanılması gereken bir konudur. Bu kapsamda değerlendirilen riskli davranışlar arasında sıklıkla antisosyal davranışlar, alkol, sigara, esrar ve diğer uyuşturucu madde kullanımı, fiziksel saldırı, intihar düşünceleri ve girişimleri, riskli cinsel davranışların yanı sıra riski cinsel davranışlar, okul terki gibi birçok problem davranış yer almaktadır (Jessor, 1991; Lindberg et al., 2000; Ögel et al., 2007). Bu davranışların ortak özellikleri ise her birinin ani veya uzun sürede gelişebilecek bir dizi sağlık problemiyle sonuçlanma potansiyeli taşıması, toplum tarafından uygun görülmemesi, ergenin gelişim görevlerini ve sosyal rollerini yerine getirmesine, başarı ve yeterlik duygusu kazanmasına engel olması şeklinde ifade edilmektedir (Jessor, 1991; Jessor, Donovan, \& Costa, 1994; Lindberg et al., 2000). Bu bağlamda ergen riskli davranışlarının ergenlerin gelişim ve uyumuna etkisinin yanı sıra kısa dönem ve uzun dönem etkilerinin değerlendirilerek etkili önleme ve müdahale çalışmalarına odaklanılması önemlidir. Özellikle okul psikolojik danışmanlığı çalışmalarında ergenlerin bu dönemde artan psikolojik yardım ihtiyaçlarına odaklanılması ve bu ihtiyaçlarının yeterince karşılanması riskli davranışlar başta olmak üzere birçok alanda olası problemler içinde koruyucu ve önleyici rol oynayacaktır (Savi-Çakar \& Kılınç, 2020). 
Riskli davranışların ergen gelişimi ve uyumuna etkisini değerlendiren çalışmalarda; koruyucu ve risk faktörleri (Jessor et al., 1994; Siyez, 2009); sosyal destek (ikiz \& Savi-Çakar, 2012; Savi-Çakar \& Tagay, 2017); aile işlevleri (Çataloğlu, 2011); riskli davranışların nedenleri (Savi-Çakar, Tagay, \& Karataş, 2015); akran zorbalığı ve psikolojik sağlamlık düzeyleri (Özdemir, 2018); öznel iyi oluş ve benlik saygısı (SaviÇakar \& Tagay, 2017); kayıp ve yas, öznel iyi oluşu artırma stratejileri ve duygu düzenleme becerileri (Akyüz, 2019) ile ebeveyn ve öğretmen istismarı (Cansız, 2019) gibi değişkenlere odaklanıldığı görülmektedir. Ayrıca, negatif yaşam olayları ve bilişsel duygu düzenleme (Garnefski, Kraaij, \& Spinhoven, 2001), çevresel risk faktörleri (Gerard \& Buehler, 2004), öz-kontrol (Quinn \& Fromme, 2010), depresyon ve intihar eğilimi (Campos \& Mesquita, 2014), sosyodemografik değişkenler, psikolojik sağlık (Piko, 2000); fiziksel istismara uğrama (Perkins \& Jones, 2004); akran desteği (Brendgen, Lamarche, Wanner, \& Vitaro, 2010); aile ile ergen iletişimi (Gutman, Eccles, Peck, \& Malanchuk, 2011), akademik başarısızlık (Girma, Hassen, \& Garuma, 2019; Pérez-Fuentes, Gázquez, Mercader, \& García-Rubira, 2011) ve genetik faktörlerin (Harden, Quinn, \& Tucker-Drob, 2012) incelendiği görülmektedir. Bu araştırmalardan yola çıkarak ergen riskli davranışlarının birçok değişkenle ilişkili olarak çok yönlü ele alınmasına ihtiyaç duyulduğu söylenebilir. Bu bağlamda bu araştırmada ergen riskli davranışları okul tükenmişliği, okula bağlanma ve öğretmen istismarı açısından incelenecektir.

Bu araştırmada riskli davranışlar ile ilişkisinin değerlendirileceği değişkenlerden okul tükenmişliği; eğitimde aşırı beklentiler ile ortaya çıkan, öğrencilerde yorgunluk hissi, duyarsızlaşma, ilgisizlik gibi belirtilerle yaşanan oldukça yaygın bir durumu tanımlamaktadır (Salmela-Aro, Savolainen, \& Holopainen, 2009). Yaşanan akademik baskının akademik strese yol açması (Yang \& Farn, 2005) ve ruh sağlığını olumsuz etkilemesi (Salmela-Aro, Upadyaya, Hakkarainen, Lonka, \& Alho, 2017) ergenler açısından da önemli bir konudur. Bu çerçevede literatürde, ergenlerde okul tükenmişliği ile ele alınan değişkenler arasında; riskli davranışlar (Salmela-Aro \& Upadyaya, 2014), depresyon (Salmela-Aro et al., 2009), psikolojik uyumsuzluk (Lee \& Lee, 2018), okul terki (Yang \& Farn, 2005), akran zorbalığı (Uzun \& Karataş, 2019) gibi sorunlara odaklanıldığı görülmektedir.

Riskli davranışlar açısından okul ile ilgili olarak değerlendirilmesi gereken bir diğer önemli değişken ise okula bağlanmadır. Okula bağlanma, okul aktivitelerine yönelik değerlilik ve yeterlilik inancını yansıtan, öğrenci motivasyonu ile okuldaki ders dışı aktiviteleri de ele alan geniş bir çerçevede açıklanmaktadır (Faircloth \& Hamm, 2005). Ergen okula bağlanma yoluyla okulun bir üyesi olarak değerli olduğuna ve saygı duyulduğuna inanma (Roeser \& Eccles, 2000), okulda öğretmenler ve sınıf arkadaşları ile kurulan ilişkiler yoluyla duygusal bağ kurma (Eccles \& Roeser, 1999) gibi temel psikolojik gereksinimlerini karşılar. Bir sosyal bağ kurma alanı olarak okul, olumlu ruh sağlığı gelişimini desteklemektedir (Roeser \& Eccles, 2000). Yukarıdaki açıklamalarda okula bağlanmanın ergen gelişimi ve uyumuna önemli bir katkı sağladığı görülmektedir. Bu bağlamda yapılan çalışmalarda okula bağlanmanın riskli davranışlar ile ilişkili olarak ele alındığı görülmektedir (Diaz, 2005; Rudasill, Reio, Stipanovic, \& Taylor 2010; Savi-Çakar, 2018).

Araştırmada riskli davranışlar ile ilgili bir diğer değişken öğretmen istismarı olup, istismar; çocuğun yaşamına, gelişimine, sağlığına veya onuruna fiilî ya da potansiyel bir zarara neden olan fiziksel, duygusal, cinsel ve ekonomik istismar ile inmâl türlerinden oluşturmaktadır. Çocuklar üzerinde bilişsel, duygusal, fiziksel ve sosyal etkileri olan istismar ve inmal telafi edilemez sonuçları ile tüm dünyada yaygın bir problemdir (WHO Raporu, 1999). İstismar sadece çocuk ve ergenin ebeveynleri ile sınırlı olmayıp aynı zamanda içinde bulunduğu geniş sosyal çevreyle de ilişkili bir durumdur ve okul ortamında öğretmen istismarı problemiyle de sık karşılaşılmaktadır (Hyman \& Snook, 1999; Theoklitou, Kabitsis, \& Kabitsi, 2012). Yapılan çalışmalarda istismara maruz kalan çocuk ve ergenlerde birçok duygusal, davranışsal, gelişimsel ve sosyal sorunlar ile intihar girişimi görülebilmektedir (Taner \& Gökler, 2004). Bununla beraber ergenlerin istismara bağlı olarak yaşadıkları psikolojik sıkıntı ve acıyı gidermek için kendine zarar verme davranışı (D'Onofrio, 2007) ve riskli davranışlar sergiledikleri belirtilmektedir (Arnow, 2004; Chen \& Liao, 2005; Fry, McCoy, \& Swales, 2012; Young \& Widom, 2014). Bu nedenle ergenlerde riskli davranışlara yönelimin açıklanmasında öğretmenden algılanan istismarın önemli olacağı düşünülmektedir. 
Riskli davranışların, yasal ve sosyal normlara aykırı davranışları içermesi, kültür tarafından onaylanmaması, otoriteye karşı olması, toplumsal yapı içerisinde problem olarak ifade edilen davranışlar olması (Jessor, 1991; Jessor et al., 1994) nedeniyle ergenlerin hem tüm yaşam alanlarında (aile, okul, akran ve toplumsal) birçok olumsuz sonuç ile ilişkili olarak değerlendirilmesi yararlı olabilir. Bu bağlamda riskli davranışlar ergenin okul yaşamını olumsuz etkileyebileceği gibi okul yaşamı ve okul ile ilgili değişkenlerde riskli davranışların ortaya çıkmasına katkı sağlayabilir. Bu değişkenler arasında öğretmen istismarı, okul tükenmişliği ve okula bağlanma düzeyinin ergen riskli davranışlarını açıklamada önemli olacağı düşünülmektedir.

Bu araştırmanın amacı, ergenlerde öğretmen istismarı, okul tükenmişliği ve okula bağlanmanın riskli davranışları yordama düzeyinin belirlenmesi ve riskli davranışların bazı demografik değişkenlere göre incelenmesidir.

Araştırmanın problemini "Öğretmen istismarı, okul tükenmişliği ve okula bağlanma değişkenleri, ergenlerin riskli davranışlarını anlamlı düzeyde yordamakta mıdır?” sorusu oluşturmaktadır.

Araştırmanın alt problemleri şu şekilde belirlenmiştir:

- Ergenlerin öğretmen istismarı, okul tükenmişliği ve okula bağlanma düzeyleri riskli davranışlarını anlamlı düzeyde yordamakta mıdır?

- Ergenlerin riskli davranışları cinsiyete, sınıf düzeyine, akademik ortalamaya, algılanan sosyoekonomik düzeye ve aile yapısına göre anlamlı düzeyde bir farklılık göstermekte midir?

\section{Yöntem}

\section{Araştırma Modeli}

Araştırmada ilişkisel tarama modeli kullanılmıştır. Iliş̧kisel tarama modeli iki ya da daha çok sayıda değişken arasında birlikte değişim olup olmadığını ve değişimin derecesini belirlemeyi amaçlayan araştırma modelidir (Karasar, 2012).

\section{Çalışma Grubu}

Araştırmanın çalışma grubu 2019-2020 eğitim öğretim yılında, Muğla ilinin Bodrum ilçesinde, ortaöğretim kurumlarında öğrenim gören ve yaş ortalaması 15.49 olan 446 öğrenciden oluşmaktadır. Örneklem seçilirken, seçkisiz örnekleme yöntemlerinden tabakalı örnekleme yöntemi kullanılmıştır. Tabakalı örnekleme, evrendeki alt grupların belirlenip bunların evren büyüklüğü içindeki oranlarıyla örneklemde temsil edilmelerini sağlamayı amaçlayan bir örnekleme yöntemidir (Büyüköztürk, KılıçÇakmak, Akgün, Karadeniz, \& Demirel, 2016). Bu bağlamda araştırmanın evreninde bulunan 4460 öğrenciden, araştırmacıların imkânları ve sınırlılıkları (zaman, para vb.) hesaplanarak; evreni temsil gücü olduğu düşünülen \%10 oranında bir örneklem oluşturulmasına karar verilmiştir (Özen \& Gül, 2007).

Oluşturulan 446 kişilik örneklemde yer alan grupların oranı, Tablo 1'de belirtilen formül ve örnek hesaplama ile belirlenmiştir (Özen \& Gül, 2007).

Tablo 1.

Örneklem Hesaplama Formülü.

\begin{tabular}{lccc}
\hline & Evrendeki Sayısı & Tabaka Ağırlığı & Örnekleme Alınacak Kadın Sayısı \\
\hline Cinsiyet & $\mathrm{Ni}$ & $\mathrm{Ni} / \mathrm{N}=\mathrm{ai}$ & ai $\times \mathrm{n}=\mathrm{ni}$ \\
Kadın & 2319 & $2319 / 4460=.52$ & $.52 \times 446=235$ \\
\hline
\end{tabular}

Öğrencilerin araştırmaya katılmaları hususunda gönüllülük esas alınmıştır. Çalışma grubu ile ilgili demografik bilgiler Tablo 2'de verilmiştir. Tablo 2 incelendiğinde katılımcıların \%52.70'inin (n=235) kız, \%42.30'unun ( $n=221$ ) ise erkek öğrencilerden oluştuğu görülmektedir. Araştırmaya katılanların \%27.13'ü ( $n=121)$ 9.sınıf, \%22.86'sı ( $n=102)$ 10.sınıf, \%23.54'ü $(n=105)$ 11.sınıf ve \%26.45'i $(n=116)$ ise 12.sınıf öğrencisidir. Katılımcıların \%11.09'u ( $n=53) 49$ ve altında, \%37.70'i ( $n=168)$ 50-69 arasında, \%36.10’u $(n=161)$ 70-84 arasında ve \%14.30’u $(n=64)$ ise 85 ve üstü akademik not ortalamasına sahiptir. 
Araştırmaya katılanların \%19.95'i ( $n=89)$ yoksul, \%39.46'sı $(n=176)$ orta ve \%40.58'i $(n=181)$ ise iyi olarak sosyoekonomik durumlarını tanımlamışlardır. Katılımcıların \%46.18'inin $(n=206)$ anne-babası birlikte, $\% 32.06$ 'sının ( $n=143)$ anne-babası ayrı ve \%21.74'ünün ( $n=97)$ ise anne ve/veya babası vefat etmiştir.

Tablo 2.

Örnekleme Ait Tanımlayıcı Istatistik Bulgular.

\begin{tabular}{llrr}
\hline Faktör & Değişken & N & \% \\
\hline Cinsiyet & Kız & 235 & 52.70 \\
& Erkek & 211 & 42.30 \\
Sınıf Düzeyi & 9. ınıf & 121 & 27.13 \\
& 10. ıııf & 102 & 22.86 \\
& 11. ınıf & 105 & 23.54 \\
& 12. ınıf & 118 & 26.45 \\
Akademik Ortalama & 49 ve altı & 53 & 11.09 \\
& $50-69$ arasında & 168 & 37.70 \\
& $70-84$ arasında & 161 & 36.10 \\
SED & 85 ve üstü & 64 & 14.30 \\
& Yoksul & 89 & 19.95 \\
& Orta & 176 & 39.46 \\
Aile Yapısı & Iyi & 181 & 40.58 \\
& Anne-baba birlikte & 206 & 46.18 \\
Toplam Öğrenci Sayısı & Anne-baba ayrı & 143 & 32.06 \\
\hline
\end{tabular}

\section{Veri Toplama Araçları}

Araştırmada veri toplama araçları olarak öğrencilere ilişkin demografik bilgilerin elde edildiği kişisel bilgi formu, Riskli Davranışlar Ölçeği, Öğretmen Duygusal İstismar Ölçeği, Okul Tükenmişliği Ölçeği ve Ergenler için Okula Bağlanma Ölçeği kullanılmıştır. Araştırmada kullanılan tüm veri toplama araçları için fikir hakkı sahiplerinden e-posta yoluyla kullanım izinleri alınmıştır. Ayrıca çalışma sağlıklı olarak yürütülebilmesi için Bodrum İlçe Milli Eğitim Müdürlüğünden gerekli izinler alınmıştır. Katılımcı öğrenciler için araştırmaya ve ölçeklere dair gerekli bilgilendirmeler yapılmıştır.

Kişisel Bilgi Formu: Araştırmaya katılan öğrencilerin demografik özellikleri hakkında bilgi edinmek amacıyla araştırmacılar tarafından kişisel bilgi formu oluşturulmuştur. Kişisel bilgi formunda öğrencilere yönelik kişisel bilgiler (cinsiyet, sınıf düzeyi, akademik ortalama, algılanan sosyoekonomik durum, aile yapısı) yer almaktadır.

Riskli Davranışlar Ölçeği (RDÖ): Ölçek Gençtanırım ve Ergene (2014) tarafından ergenlerin riskli davranışlarını ölçmek için Türk kültürüne özgü olarak geliştirilmiştir. Ölçek toplam 36 madde ve 5'li Likert tipindedir. Ölçekten alınan puanın yükselmesi, bireyin riskli davranış düzeyinin yükseldiğine işaret etmektedir. Ölçeğin 'antisosyal davranışları' (7 madde), 'alkol kullanımını' (7 madde), 'sigara kullanımın' (6 madde), 'intihar eğilimini' (4 madde), 'beslenme alışkanlıklarını' (5 madde) ve 'okul terkini' (7 madde) ölçen altı alt boyutu bulunmaktadır ve ölçekten toplam puan alınabilmektedir. Ölçek toplam varyansın \%55.43'ünü açıklamaktadır. RDÖ’nün genel iç tutarlık katsayısı .90’dır (Gençtanırım \& Ergene, 2014).

RDÖ’nün bu çalışma kapsamında kullanılabilmesi için öncelikle güvenirlik ve geçerlik çalışmaları yapılmıştır. Güvenirlik çalışması için ölçeğin Cronbach alfa iç tutarlık katsayısı hesaplanmış ve .93 olarak bulunmuştur. Ölçeğin yapı geçerliğinin test edilmesi için Doğrulayıcı Faktör Analizi (DFA) yapılmış ve uyum indekslerinin anlamlı olduğu görülmüştür $\left(X^{2}=920.64, s d=324, p=.00, X^{2} / s d=2.84, R M S E A=.07\right.$, $\mathrm{SRMR}=.08, \mathrm{CFI}=.92$, NNFI=.91). Bu değerler göz önüne alındığında ölçeğin araştırmada kullanılabilecek düzeyde güvenilir ve geçerli olduğu söylenebilir (Kline, 2014). 
Öğretmen Duygusal istismar Ölçeği (ÖDiö): ÖDiö, Kırımsoy ve Kaner (2001) tarafından öğretmenlerin ergenler üzerindeki duygusal istismar düzeyini ölçmek için Türk kültürüne özgü olarak geliştirilmiştir. Ölçek toplam 27 madde ve $5^{\prime} l i$ Likert tipindedir. Ölçekten alınan puanın yükselmesi, bireyin yoğun düzeyde öğretmen istismarına uğradığına işaret etmektedir. Ölçeğin 'reddetme ve aşağılamayı' (9 madde), 'yıldırmayı' (9 madde) ve 'duyarsızlı̆ı' (9 madde) ölçen üç alt boyutu bulunmaktadır ve ölçekten toplam puan alınabilmektedir. ÖDiö’nün genel iç tutarlık katsayısı .70'dir (Kırımsoy \& Kaner, 2001; akt. Kırımsoy, 2003).

ÖDiö’nün bu çalışma kapsamında kullanılabilmesi için öncelikle güvenirlik ve geçerlik çalışmaları yapılmışır. Güvenirlik çalışması için ölçeğin Cronbach alfa iç tutarlık katsayısı hesaplanmış ve .83 olarak bulunmuştur. Ölçeğin yapı geçerliğinin test edilmesi için DFA yapılmış ve uyum indekslerinin anlamlı olduğu görülmüştür ( $\mathrm{X}^{2}=2365.54, \mathrm{sd}=827, \mathrm{p}=.00, \mathrm{X}^{2} / \mathrm{sd}=2.86, \mathrm{RMSEA}=.07, \mathrm{SRMR}=.09, \mathrm{CFI}=.90, \mathrm{NNFI}=.92$ ). Bu değerler göz önüne alındığında ölçeğin araştırmada kullanılabilecek düzeyde güvenilir ve geçerli olduğu söylenebilir (Kline, 2014).

Okul Tükenmişliği Ölçeği (ОтÖ): OTÖ, Salmela-Aro, Kiuru, Leskinen ve Nurmi (2009) tarafından öğrencilerin okula dair yaşadıkları tükenmişliği ölçmek amacıyla geliştirilmiştir. Ölçeğin Türk kültürüne uyarlaması Seçer, Halmatov, Veyis ve Ateş (2013) tarafından yapılmıştır. Ölçek toplam 9 madde ve 5'li Likert tipindedir. Ölçekten alınan puanın yükselmesi, bireyin okul tükenmişliğinin de yükseldiğine işaret etmektedir. Ölçeğin 'duygusal tükenmişliği' (4 madde), 'duyarsızlaşmayı' (3 madde) ve 'düşük başarı beklentisini' ( 2 madde) ölçen üç alt boyutu bulunmaktadır ve ölçekten toplam puan alınabilmektedir. Ölçek toplam varyansın \%66.85'ini açıklamaktadır. OTÖ'nün genel iç tutarlık katsayısı .75'dir (Seçer et al., 2013).

OTÖ’nün bu çalışma kapsamında kullanılabilmesi için öncelikle güvenirlik ve geçerlik çalışmaları yapılmışıı. Güvenirlik çalışması için ölçeğin Cronbach alfa iç tutarlık katsayısı hesaplanmış ve .91 olarak bulunmuştur. Ölçeğin yapı geçerliğinin test edilmesi için DFA yapılmış ve uyum indekslerinin anlamlı olduğu görülmüştür ( $X^{2}=1305.81$, sd=524, $p=.00, X^{2} / s d=2.49$, RMSEA=.05, SRMR=.06, CFI=.95, NNFI=.94). Bu değerler göz önüne alındığında ölçeğin araştırmada kullanılabilecek düzeyde güvenilir ve geçerli olduğu söylenebilir (Kline, 2014).

Ergenler için Okula Bağlanma Ölçeği (EOBÖ): ЕOBÖ, Hill ve Werner (2006) tarafından çocuk ve ergenlerin okula bağlanma düzeylerini değerlendirmek amacıyla geliştirilmiştir. Ölçeğin Türk kültürüne uyarlaması Savi-Çakar (2011a) tarafından yapılmışır. Ölçek toplam 14 madde ve 5'li Likert tipindedir. Ölçekten alınan puanın yükselmesi, bireyin yoğun düzeyde okula bağlandığına işaret etmektedir. Ölçeğin 'okula bağlanmayı' (5 madde), 'öğretmene bağlanmayı' (5 madde) ve 'arkadaşa bağlanmayı' (4 madde) ölçen üç alt boyutu bulunmaktadır ve ölçekten toplam puan alınabilmektedir. Ölçek toplam varyansın \%58.69'unu açıklamaktadır. EOBÖ’nün genel iç tutarlık katsayısı .84'tür (Savi-Çakar, 2011a).

EOBÖ’nün bu çalışma kapsamında kullanılabilmesi için öncelikle güvenirlik ve geçerlik çalışmaları yapılmıştır. Güvenirlik çalışması için ölçeğin Cronbach alfa iç tutarlık katsayısı hesaplanmış ve .91 olarak bulunmuştur. Ölçeğin yapı geçerliğinin test edilmesi için DFA yapılmış ve uyum indekslerinin anlamlı olduğu görülmüştür ( $\left.\mathrm{X}^{2}=1020.54, \mathrm{sd}=425, \mathrm{p}=.00, \mathrm{X}^{2} / \mathrm{sd}=2.40, \mathrm{RMSEA}=.06, \mathrm{SRMR}=.06, \mathrm{CFI}=.92, \mathrm{NNFI}=.90\right)$. Bu değerler göz önüne alındığında ölçeğin araştırmada kullanılabilecek düzeyde güvenilir ve geçerli olduğu söylenebilir (Kline, 2014).

\section{Verilerin Toplanması}

Verilerin toplanma sürecinde araştırmacılar, örneklemde yer alan okullara ve verilerin toplanacağı her bir sınıfa ayrı ayrı girmiş, öğrencilere araştırmanın amaç ve içeriği ile ölçekler hakkında gerekli açıklamalar yapılımışır. Araştırmaya katılma konusunda gönüllü olan katılımcılardan imzalı olarak bilgilendirilmiş onam formları alınmıştır. Daha sonra ölçeklerin öğrenciler tarafından doldurulması sağlanmıştır. Uygulama ortalama 30 dakika sürmüştür. Tamamlanan ölçekler incelenmiş ve öğrenciler tarafından tam olarak doldurulmayan ölçekler çalışma kapsamına alınmamıştır. 


\section{Verilerin Analizi}

Veriler üzerinde istatistiki işlemlerin yapılabilmesi için öncelikle toplanan veriler SPSS 20.0 programına aktarılmıştır. Daha sonra veri setinde hatasızlık kontrol edilmiş, tüm değerlerin olası sınırlar (ranj) içinde olduğu tespit edilmiştir (Tabachnick, Fidell, \& Ullman, 2007). Ayrıca ters puanlanan maddeler düzeltilmiş; veri seti, kayıp veri incelemesi için hazır hale getirilmiştir. Daha sonra veri setindeki kayıp veri oranı incelenmiş ve bu oranın \%5'ten az olduğu tespit edilmiştir. Kayıp veri örüntüsünün rastlantısal dağılıp dağılmadığı kontrol edilmiş, Little's MCAR testi sonucunun beklendiği gibi anlamsız çıktığı ( $p=.19>.05)$ ve kayıp verilerin rastlantısal dağıldığı anlaşılmıştır (Little, 1988). Toplam kayıp veri oranının \%5'in altında kalması ve veri setinin rastlantısal dağılmasından dolayı kayıp verilere Beklenti Maksimizasyonu (EM) ile kayıp değer ataması yapılmıştır (Tabachnick et al., 2007).

Veri setindeki uç değerlerin tespit edilmesi için tek değişkenli ve çok değişkenli uç değer incelemesi yapılmıştır. Öncelikle tek değişkenli uç değer incelemesi için z testi yapılmış, örneklem büyüklüğünün 100 'den fazla olmasından dolayı z puanı referans değeri olarak -4.00 ile +4.00 arası alınmıştır (Mertler \& Vannatta, 2005). Standartlaştırılmış z puanı -4.00 ile +4.00 aralığının dışında kalan herhangi bir veriye rastlanılmamıştır. Daha sonra çok değişkenli uç değer incelemesi için Mahalonobis uzaklık katsayısı testi yapılmış ancak uç değer ifade eden herhangi bir veriye rastlanmamıştır (Tabachnick et al., 2007).

Her bir değişkenin, normallik varsayımını sağlayıp sağlamadığının test edilmesi için basıklık (Kurtosis) ve çarpıklık (Skewness) katsayılarına bakılmıştır. Değişkenlerin her biri için basıklık ve çarpıklık katsayılarının referans değer aralığı olan -1.00 ve +1.00 arasında yer aldığı görülmüştür. Bu bağlamda verilerin normal dağıldığı söylenebilir (Çokluk, Şekercioğlu, \& Büyüköztürk, 2014).

Veri setinde çoklu bağlantı problemi olup olmadığını kontrol etmek için değişkenler arasındaki basit (ikili) korelasyonlara bakılmıştır. Yapılan analiz sonrasında değişkenler arasındaki ikili korelasyon değerlerinin hepsinin .90'dan düşük olduğu görülmüştür (Çokluk et al., 2014). Ayrıca veri setinde çoklu bağlantı probleminin olup olmadığının belirlenmesi için VIF ve $\mathrm{Cl}$ değerlerine de bakılmış; tüm maddeler için VIF değerlerinin 10'dan (Webster, 1992; akt. Albayrak, 2005), Cl değerlerinin de 30'dan küçük (Gujarati, 1995; akt. Albayrak, 2005) olduğu görülmüştür. Bu bağlamda değişkenler arasında çoklu bağlantı sorununun olmadığı söylenebilir.

Veriler analiz işlemleri için hazır hale getirildikten sonra öncelikle Riskli Davranışlar Ölçeğinin, Öğretmen Duygusal İstismar Ölçeğinin, Okul Tükenmişliği Ölçeğinin ve Ergenler için Okula Bağlanma Ölçeğinin çalışma kapsamında kullanılabilmesi için güvenirlik ve geçerlik çalışmaları yapılmıştır. Güvenirlik değerlerinin test edilmesi için ölçeklere Cronbach alfa iç tutarlık katsayısı; geçerlik değerlerinin test edilmesi için ise LISREL 8.7 programı kullanılarak DFA yapılmıştır. Ulaşılan değerler, ölçeklerin araştırmada kullanılabilecek düzeyde güvenilir ve geçerli olduğunu göstermektedir. Bu değerler, araştırmanın veri toplama araçları ile ilgili kısmında sunulmaktadır.

Yapılan işlemlerle verilerin regresyon analizi için gerekli olan parametrik özellikleri karşıladığı tespit edilmiştir. Bu bağlamda araştırma sorularına cevap bulmak adına: Değişkenler arasındaki ilişkiyi saptamak için Pearson Korelasyon Katsayısı Analizi; öğretmen istismarı, okul tükenmişliği ve okula bağlanmanın ergenlerin riskli davranışlarını ne ölçüde yordadığını anlayabilmek için ise Çoklu Doğrusal Regresyon Analizi kullanılmıştır. Verilerin homojenlik varsayımını sağlayıp sağlamadığının test edilmesi için Levene Testi yapılmış ve homojenlik varsayımının sağlandığı anlaşılmıştır $(p<.51)$. Bunun üzerine farklılıklara ilişkin analiz için ilişkisiz örneklemler t-testi ile tek yönlü varyans analizi (ANOVA) kullanılmıştır (Büyüköztürk, 2014). Farklılıkların kaynağını test etmek adına, örneklemin kategorilerdeki dağılımları gözetilerek; Tukey veya Hochberg's GT2 testlerinden uygun olanı kullanılmıştır (Field, 2005). Ayrıca ilişkisiz örneklemler için t-testinde Cohen'in d (Cohen, 1988); tek yönlü varyans analizi için ise Omega kare (Kirk, 1996) etki büyüklüğü hesaplama formülleri kullanılmış, anlamlılık düzeyi olarak .05 alınmıştır. 


\section{Bulgular}

Ergenlerin öğretmen istismarı, okul tükenmişliği ve okula bağlanma düzeylerinin riskli davranışlarını ne ölçüde yordadığını ortaya koymak için çoklu doğrusal regresyon analizi yapılmıştır. Regresyon analizi yapılmadan önce bağımlı ve bağımsız değişkenler arasında çoklu bağlantının olup olmadığıı belirlemek amacıyla bağımlı ve bağımsız değişkenler arasındaki ikili korelasyon katsayıları hesaplanmış ve ortaya çıkan sonuçlar Tablo 3'te gösterilmiştir.

Tablo 3.

Değişkenler Arası Pearson Momentler Çarpımı Korelasyon Katsayıları.

\begin{tabular}{lrrrrrr}
\hline Değişkenler & $\mathbf{X}$ & $\mathbf{S}$ & $\mathbf{1}$ & $\mathbf{2}$ & $\mathbf{3}$ & $\mathbf{4}$ \\
\hline Riskli Davranışlar & 78.90 & 24.81 & - & & & \\
Öğretmen İstismarı & 48.37 & 12.34 & $.51^{* *}$ & - & & \\
Okul Tükenmişliği & 26.71 & 9.94 & $.30^{* *}$ & $.34^{* *}$ & - & \\
Okula Bağlanma & 48.37 & 12.34 & $-.37^{* *}$ & $-.40^{* *}$ & $-.45^{* *}$ & \\
\hline
\end{tabular}

$* * p<.01$

Tablo 3'e göre katılımcıların riskli davranışları ortalamasının 78.90, standart sapmasının ise 24.81 olduğu görülmektedir. Ayrıca ergenlerin riskli davranışları ile öğretmen istismarı $(r=.51, p<.01)$ ve okul tükenmişliği $(r=.30, p<.01)$ düzeyleri arasında pozitif yönde; okula bağlanma $(r=-.37, p<.01)$ düzeyleri arasında ise negatif yönde anlamlı bir ilişki vardır. Bu ilişkilerin kurgulanan modelde çoklu bağlantı sorunu oluşturacak düzeyde olmadığı (.90’dan küçük olduğu); verilerin analizi bölümünde verilmiş olan regresyon varsayımı için yapılan analizlerden de anlaşılmaktadır (Çokluk et al., 2014). Ayrıca elde edilen korelasyon katsayıları incelendiğinde, ergenlerin riskli davranışları ile öğretmen istismarı, okul tükenmişliği ve okula bağlanma düzeyleri arasında orta $(.30<r<.70)$ düzeyde bir ilişkinin var olduğu görülmektedir (Büyüköztürk, 2014).

Ergenlerin öğretmen istismarı, okul tükenmişliği ve okula bağlanma düzeylerinin riskli davranışlarını anlamlı olarak yordayıp yordamadığını belirlemek için yapılan çoklu doğrusal regresyon analizinden elde edilen sonuçlar Tablo 4'te verilmiştir.

Tablo 4.

Riskli Davranışların Yordayıcısı Olarak Öğretmen Istismarı, Okul Tükenmişliği ve Okula Bağlanma Düzeylerine iliş̧kin Çoklu Doğrusal Regresyon Analizi Sonuçları.

\begin{tabular}{|c|c|c|c|c|c|c|c|c|c|}
\hline Değişkenler & $\mathbf{R}$ & $\mathbf{R}^{2}$ & $\mathbf{R}_{\mathrm{ch}}^{2}$ & $\mathbf{F}$ & Df & B & $\beta$ & $\mathbf{t}$ & $\mathbf{p}$ \\
\hline Sabit & .55 & .31 & .30 & $64.23 * *$ & $3 / 442$ & 67.11 & & $6.82 * *$ & .00 \\
\hline Öğretmen İst & & & & & & .12 & .09 & $.18^{* *}$ & .00 \\
\hline Okul Tükenm & & & & & & .13 & .10 & $1.83^{* *}$ & .00 \\
\hline Okula Bağlan & & & & & & -.22 & -.31 & $-2.55^{* *}$ & .00 \\
\hline
\end{tabular}

$* * \mathrm{p}<.01$

Tablo 4'te görülen çoklu doğrusal regresyon analizi sonuçlarına göre öğretmen istismarı, okul tükenmişliği ve okula bağlanma değişkeni, ergenlerin riskli davranış puanlarını anlamlı olarak yordamakta ve regresyon için kurgulanan modelin anlamlı olduğu görülmektedir $\left(R=.55, R^{2}=.31\right.$, $\left.F_{(3,442)}=64.23, p<.01\right)$. Kurgulanan regresyon modelinde belirtilen tüm bu değişkenler, ergenlerin riskli davranışları üzerinde büyük etki $\left(R^{2}>\right.$.26) değerine sahiptir (Cohen, 1988). Ayrıca öğretmen istismarı, okul tükenmişliği ve okula bağlanma değişkenleri ergenlerin riskli davranışlarının \%31'ini açıklamaktadır.

Standardize edilmiş regresyon katsayısına $(\beta)$ göre yordayıcı değişkenlerin, ergenlerin riskli davranış düzeyleri üzerindeki göreli önem sırası; okula bağlanma ( $\beta=-.31, t=-2.55)$, okul tükenmişliği $(\beta=.10$, $\mathrm{t}=1.83)$ ve öğretmen istismarı $(\beta=.09, \mathrm{t}=.18)$ şeklinde sıralanmaktadır. Regresyon katsayılarının anlamlılığına ilişkin $t$-testi sonuçları incelendiğinde: Öğretmen istismarı $(t=.18, p<.01)$ ve okul tükenmişliği $(t=1.83, p<.01)$ değişkenleri pozitif; okula bağlanma $(t=-2.55, p<.01)$ değişkeni ise negatif yönde ergenlerin riskli davranışları üzerinde anlamlı birer yordayıcı olduğu görülmektedir. 
Bu sonuçlar göz önüne alındığında, ergenlerin okul tükenmişliği ve öğretmen istismarı değişkenlerinden aldıkları puanların yükselmesiyle birlikte riskli davranış düzeylerinin artacağı; ancak okula bağlanma değişkenindeki puan artışlarının ise riskli davranışlarını azaltacağı söylenebilir.

Ergenlerin cinsiyet açısından riskli davranış puanları arasındaki farkın anlamlı olup olmadığını incelenmek için ilişkisiz örneklemler t-testi analizi gerçekleştirilmiş ve sonuçlar Tablo 5'te sunulmuştur.

Tablo 5.

Ergenlerin Cinsiyet Açısından Riskli Davranış Puanlarının Incelenmesine Yönelik Ilişkisiz Örneklemler TTesti Sonuçları.

\begin{tabular}{|c|c|c|c|c|c|c|c|c|}
\hline & Cinsiyet & $\mathbf{n}$ & $\bar{x}$ & $\mathbf{S}$ & sd & $\mathbf{t}$ & $p$ & Cohen's d \\
\hline Toplam Riskli & $\mathrm{K} 1 \mathrm{z}$ & 235 & 75.31 & 23.19 & 444 & $-.3 .26 * *$ & .00 & .61 \\
\hline Davranışlar & Erkek & 211 & 82.90 & 25.96 & & & & \\
\hline \multicolumn{2}{|c|}{ Antisosyal Davranışlar Kız } & 235 & 15.24 & 6.61 & 444 & $-3.06 * *$ & .00 & .55 \\
\hline & Erkek & 211 & 17.12 & 6.30 & & & & \\
\hline \multirow[t]{2}{*}{ Alkol Kullanımı } & $\mathrm{K} ı \mathrm{Z}$ & 235 & 10.60 & 6.15 & 444 & $-3.18 * *$ & .00 & .57 \\
\hline & Erkek & 211 & 12.67 & 7.54 & & & & \\
\hline \multirow[t]{2}{*}{ Sigara Kullanımı } & $\mathrm{K} ı \mathrm{Z}$ & 235 & 11.54 & 5.54 & 444 & $-1.91^{*}$ & .04 & .51 \\
\hline & Erkek & 211 & 12.59 & 6.07 & & & & \\
\hline \multirow[t]{2}{*}{ İntihar Eğilimi } & $\mathrm{K} ı \mathrm{Z}$ & 235 & 14.59 & 4.72 & 444 & -.57 & .56 & .04 \\
\hline & Erkek & 211 & 14.86 & 5.12 & & & & \\
\hline Beslenme & $\mathrm{K} ı \mathrm{Z}$ & 235 & 12.34 & 5.48 & 444 & $-3.12 * *$ & .00 & .58 \\
\hline Alışkanlıkları & Erkek & 211 & 13.68 & 6.28 & & & & \\
\hline \multirow[t]{2}{*}{ Okul Terki } & $\mathrm{K} ı \mathrm{Z}$ & 235 & 10.88 & 5.56 & 444 & $-4.89 * *$ & .00 & .64 \\
\hline & Erkek & 211 & 13.81 & 7.08 & & & & \\
\hline
\end{tabular}

$* * \mathrm{p}<.01, * \mathrm{p}<.05$

Tablo 5'te görüldüğü gibi kız ve erkek ergenlerin toplam riskli davranış puanları $\left(\mathrm{t}_{(444)}=-3.26, \mathrm{p}<.01\right.$, $d=.61$ ) anlamlı olarak farklılaşmaktadır. Ergenlerin riskli davranışlarının alt boyutlarına bakıldığında; kız ve erkek ergenlerin antisosyal davranışlar $\left(\mathrm{t}_{(444)}=-3.06, \mathrm{p}<.01, d=.55\right)$, alkol kullanımı $\left(\mathrm{t}_{(444)}=-3.18, \mathrm{p}<.01\right.$, $d=.57)$, sigara kullanımı $\left(\mathrm{t}_{(444)}=-1.91, \mathrm{p}<.05, d=.51\right)$, beslenme alışkanlıkları $\left(\mathrm{t}_{(444)}=-3.12, \mathrm{p}<.01, d=.58\right)$ ve okul terki $\left(\mathrm{t}_{(444)}=-4.89, \mathrm{p}<.01, d=.64\right)$ puanlarının anlamlı olarak farklılaşmakta olduğu görülmektedir. Diğer bir deyişle, erkek ergenlerin toplam riskli davranış, antisosyal davranışlar, alkol kullanımı, sigara kullanımı, beslenme alışkanlıkları ve okul terki puan ortalamalarının; kız ergenlerin puan ortalamalarından daha yüksek olduğu görülmektedir. Ancak Tablo 5 incelendiğinde kız ve erkek ergenlerin intihar eğilimi puanlarının $\left(\mathrm{t}_{(444)}=-.57, \mathrm{p}>.05\right)$ anlamlı düzeyde farklılaşmadığı belirlenmiştir. Ayrıca Tablo 5'te görüldüğü gibi cinsiyetin, ergenlerin toplam riskli davranış ( $d=.61)$, antisosyal davranışlar $(d=.55)$, alkol kullanımı $(d=.57)$, sigara kullanımı $(d=.51)$, beslenme alışkanlıkları $(d=.58)$ ve okul terki $(d=.64)$ puan ortalamaları üzerindeki etki büyüklüğünün orta düzeyde olduğu görülmüştür (Cohen, 1988).

Ergenlerin sınıf düzeylerine göre riskli davranış puanları arasındaki farkın anlamlı olup olmadığını saptamaya yönelik tek yönlü varyans analizi yapılmış, sonuçlar Tablo 6'da gösterilmiştir. Tablo 6'da görüldüğü üzere ergenlerin sınıf düzeyleri ile toplam riskli davranış puanları arasında bulunan fark istatistiksel olarak anlamlıdır $\left(F_{(3,442)}=1.73, p<.05, \Omega^{2}=.08\right)$. Buna göre, 12.sınıf öğrencilerinin 9.sınıf öğrencilerine göre daha çok riskli davranışlar sergiledikleri söylenebilir. Ergenlerin riskli davranışlarının alt boyutlarına bakıldığında; alkol kullanımı $\left(F_{(3,442)}=3.49, p<.05, \Omega^{2}=.11\right)$, sigara kullanımı $\left(F_{(3,442)}=4.43\right.$, $\left.\mathrm{p}<.01, \Omega^{2}=.12\right)$ ve beslenme alışkanlıkları puanlarının $\left(F_{(3,442)}=3.26, p<.05, \Omega^{2}=.10\right)$ sınıf düzeylerine göre anlamlı olarak farklılaşmakta olduğu görülmektedir. Ancak ergenlerin antisosyal davranışlar $\left(F_{(3,442)}=.84\right.$, $\left.p>.05, \Omega^{2}=.01\right)$, intihar eğilimi $\left(F_{(3,442)}=1.18, p>.05, \Omega^{2}=.01\right)$ ve okul terki $\left(F_{(3,442)}=.82, p>.05, \Omega^{2}=.00\right)$ puanlarının sınıf düzeylerine göre anlamlı olarak farklılaşmadığı görülmektedir. Ayrıca sınıf düzeylerinin, ergenlerin toplam riskli davranış $\left(\Omega^{2}=.08\right)$, alkol kullanımı $\left(\Omega^{2}=.11\right)$, sigara kullanımı $\left(\Omega^{2}=.12\right)$ ve beslenme alışkanlıkları $\left(\Omega^{2}=.10\right)$ puan ortalamaları üzerindeki etki büyüklüğünün orta düzeyde olduğu anlaşılmaktadır (Kirk, 1996). 
Tablo 6.

Ergenlerin Sınıf Düzeylerine Göre Riskli Davranış Puanlarının Incelenmesine Ilişskin Tek Yönlü Varyans Analizi Sonuçları.

\begin{tabular}{|c|c|c|c|c|c|c|c|c|}
\hline & Sınıf Düzeyi & $\mathbf{n}$ & $\bar{x}$ & $S$ & $\mathbf{F}$ & $\mathbf{p}$ & Fark & $\Omega^{2}$ \\
\hline Toplam Riskli & 9.sinif (A) & 121 & 75.75 & 23.26 & $1.73^{*}$ & .04 & A-D & .08 \\
\hline \multirow[t]{3}{*}{ Davranışlar } & 10.sinıf (B) & 102 & 78.42 & 23.42 & & & & \\
\hline & 11.sinıf (C) & 105 & 80.39 & 24.78 & & & & \\
\hline & 12.sinıf (D) & 118 & 82.13 & 27.09 & & & & \\
\hline Antisosyal & 9.sınıf (A) & 121 & 15.49 & 6.31 & .861 & .46 & Yok & .01 \\
\hline \multirow[t]{3}{*}{ Davranışlar } & 10.sınıf (B) & 102 & 16.38 & 6.69 & & & & \\
\hline & 11.sınıf (C) & 105 & 16.63 & 6.33 & & & & \\
\hline & 12.sınıf (D) & 118 & 16.46 & 6.89 & & & & \\
\hline \multirow[t]{4}{*}{ Alkol Kullanımı } & 9.sınıf (A) & 121 & 10.63 & 6.48 & $3.49 *$ & .01 & $A-D$ & .11 \\
\hline & 10.sınıf (B) & 102 & 10.57 & 6.47 & & & & \\
\hline & 11.sınıf (C) & 105 & 11.88 & 7.00 & & & & \\
\hline & 12.sınIf (D) & 118 & 13.06 & 7.37 & & & & \\
\hline \multirow[t]{4}{*}{ Sigara Kullanım } & 19.sinıf (A) & 121 & 11.09 & 5.24 & $4.43^{* *}$ & .00 & $A-D$ & .12 \\
\hline & 10.sınıf (B) & 102 & 11.12 & 5.43 & & & & \\
\hline & 11.sinıf (C) & 105 & 12.47 & 5.86 & & & & \\
\hline & 12.sinıf (D) & 118 & 13.37 & 6.39 & & & & \\
\hline \multirow[t]{4}{*}{ İntihar Eğilimi } & 9.sınıf (A) & 121 & 14.87 & 4.45 & 1.18 & .31 & Yok & .01 \\
\hline & 10.sınıf (B) & 102 & 15.64 & 3.98 & & & & \\
\hline & 11.sinıf (C) & 105 & 14.19 & 4.81 & & & & \\
\hline & 12.sınıf (D) & 118 & 14.50 & 5.84 & & & & \\
\hline Beslenme & 9.sınıf (A) & 121 & 12.51 & 6.26 & $3.26^{*}$ & .02 & $A-D$ & .10 \\
\hline \multirow[t]{3}{*}{ Alışkanlıkları } & 10.sinıf (B) & 102 & 13.40 & 6.45 & & & & \\
\hline & 11.sinıf (C) & 105 & 13.65 & 7.41 & & & & \\
\hline & 12.sınıf (D) & 118 & 13.78 & 7.88 & & & & \\
\hline \multirow[t]{4}{*}{ Okul Terki } & 9.sinıf $(A)$ & 121 & 11.81 & 6.48 & .82 & .48 & Yok & .00 \\
\hline & 10.sinıf (B) & 102 & 11.73 & 5.89 & & & & \\
\hline & 11.sınıf (C) & 105 & 12.79 & 6.60 & & & & \\
\hline & 12.sınıf (D) & 118 & 12.72 & 6.68 & & & & \\
\hline
\end{tabular}

$* * p<.01, * p<.05$

Ergenlerin akademik ortalamalarına göre riskli davranış puanları arasındaki farkın anlamlı olup olmadığını saptamaya yönelik tek yönlü varyans analizi yapılmış, sonuçlar Tablo 7'de sunulmuştur.

Tablo 7'de görüldüğü üzere ergenlerin akademik ortalamaları ile toplam riskli davranış puanları arasında bulunan fark istatistiksel olarak anlamlıdır $\left(F_{(4,441)}=4.67, p<.01, \Omega^{2}=.13\right)$. Buna göre, akademik ortalaması 49 ve altında olan öğrencilerin, akademik ortalaması 85 ve üstü olan öğrencilere göre daha çok riskli davranışlar sergiledikleri söylenebilir. Ergenlerin riskli davranışlarının alt boyutlarına bakıldığında; antisosyal davranışlar $\left(F_{(4,441)}=3.25, p<.05, \Omega^{2}=.10\right)$, alkol kullanımı $\left(F_{(4,441)}=4.00, p<.01\right.$, $\left.\Omega^{2}=.11\right)$, sigara kullanımı $\left(F_{(4,441)}=3.23, p<.05, \Omega^{2}=.09\right)$, beslenme alışkanlıkları $\left(F_{(4,441)}=3.24, p<.01, \Omega^{2}=.10\right)$ ve okul terki $\left(\mathrm{F}_{(4,441)}=4.60, \mathrm{p}<.01, \Omega^{2}=.13\right)$ puanlarının akademik ortalamalarına göre anlamlı olarak farklılaşmakta olduğu görülmektedir. Ancak ergenlerin intihar eğilimi puanlarının $\left(F_{(4,441)}=.57, p>.05\right.$, $\left.\Omega^{2}=.00\right)$ akademik ortalamalarına göre anlamlı düzeyde farklılaşmadı̆̆ı söylenebilir. Ayrıca akademik ortalamaların, ergenlerin toplam riskli davranış $\left(\Omega^{2}=.13\right)$, antisosyal davranışlar $\left(\Omega^{2}=.10\right)$, alkol kullanımı $\left(\Omega^{2}=.11\right)$, sigara kullanımı $\left(\Omega^{2}=.09\right)$, beslenme alışkanlıkları $\left(\Omega^{2}=.10\right)$ ve okul terki $\left(\Omega^{2}=.13\right)$ puan ortalamaları üzerindeki etki büyüklüğünün orta düzeyde olduğu anlaşılmaktadır (Kirk, 1996).

Ergenlerin algıladıkları sosyoekonomik düzeylerine göre riskli davranış puanları arasındaki farkın anlamlı olup olmadığını saptamaya yönelik tek yönlü varyans analizi yapılmış, sonuçlar Tablo 8’de gösterilmiştir. 
Tablo 7.

Ergenlerin Akademik Ortalamalarına Göre Riskli Davranış Puanlarının incelenmesine Ilişkin Tek Yönlü Varyans Analizi Sonuçları.

\begin{tabular}{|c|c|c|c|c|c|c|c|c|}
\hline & Not Ortalaması & $\mathbf{n}$ & $\bar{x}$ & $S$ & $\mathbf{F}$ & $\mathbf{p}$ & Fark & $\Omega^{2}$ \\
\hline Toplam Riskli & 49 ve altı $(A)$ & 53 & 85.36 & 26.67 & $4.67 * *$ & .00 & A-D & .13 \\
\hline \multirow[t]{3}{*}{ Davranışlar } & $50-69$ arasında (B) & 168 & 83.47 & 25.32 & & & & \\
\hline & $70-84$ arasında (C) & 161 & 74.34 & 22.86 & & & & \\
\hline & 85 ve üstü (D) & 64 & 73.32 & 23.84 & & & & \\
\hline Antisosyal & 49 ve altı $(A)$ & 53 & 18.00 & 7.26 & $3.25^{*}$ & .01 & $A-D$ & .10 \\
\hline \multirow[t]{3}{*}{ Davranışlar } & 50-69 arasında (B) & 168 & 16.95 & 6.63 & & & & \\
\hline & $70-84$ arasında (C) & 161 & 15.05 & 6.03 & & & & \\
\hline & 85 ve üstü (D) & 64 & 15.21 & 6.41 & & & & \\
\hline \multirow{4}{*}{ Alkol Kullanımı } & 49 ve altı $(A)$ & 53 & 13.07 & 7.22 & $4.00 * *$ & .00 & $A-D$ & .11 \\
\hline & $50-69$ arasında (B) & 168 & 12.81 & 7.24 & & & & \\
\hline & $70-84$ arasında $(\mathrm{C})$ & 161 & 10.50 & 6.57 & & & & \\
\hline & 85 ve üstü (D) & 64 & 9.90 & 5.91 & & & & \\
\hline Sigara & 49 ve altı $(A)$ & 53 & 12.51 & 6.19 & $3.23^{*}$ & .01 & $A-D$ & .09 \\
\hline \multirow[t]{3}{*}{ Kullanımı } & 50-69 arasında (B) & 168 & 11.88 & 6.22 & & & & \\
\hline & $70-84$ arasında (C) & 161 & 11.32 & 5.41 & & & & \\
\hline & 85 ve üstü (D) & 64 & 10.60 & 4.87 & & & & \\
\hline \multirow[t]{4}{*}{ İntihar Eğilimi } & 49 ve altı $(A)$ & 53 & 15.44 & 4.97 & .57 & .68 & Yok & .00 \\
\hline & $50-69$ arasında (B) & 168 & 14.80 & 5.38 & & & & \\
\hline & $70-84$ arasında (C) & 161 & 14.64 & 4.59 & & & & \\
\hline & 85 ve üstü (D) & 64 & 14.12 & 4.39 & & & & \\
\hline Beslenme & 49 ve altı $(A)$ & 53 & 15.18 & 7.01 & $3.24 * *$ & .00 & $A-D$ & .10 \\
\hline \multirow[t]{3}{*}{ Alışkanlıkları } & $50-69$ arasında (B) & 168 & 14.72 & 6.86 & & & & \\
\hline & $70-84$ arasında (C) & 161 & 12.46 & 6.45 & & & & \\
\hline & 85 ve üstü (D) & 64 & 11.91 & 5.96 & & & & \\
\hline \multirow[t]{4}{*}{ Okul Terki } & 49 ve altı $(A)$ & 53 & 13.81 & 6.71 & $4.60 * *$ & .00 & $A-D$ & .13 \\
\hline & $50-69$ arasında (B) & 168 & 13.48 & 6.74 & & & & \\
\hline & $70-84$ arasında (C) & 161 & 10.73 & 5.44 & & & & \\
\hline & 85 ve üstü (D) & 64 & 11.79 & 7.28 & & & & \\
\hline
\end{tabular}

$* * \mathrm{p}<.01, * \mathrm{p}<.05$

Tablo 8'de görüldüğü gibi ergenlerin algıladıkları sosyoekonomik durumları ile toplam riskli davranış puanları arasında bulunan fark istatistiksel olarak anlamlıdır $\left(F_{(2,443)}=14.36, p<.01, \Omega^{2}=.13\right)$. Buna göre, sosyoekonomik düzeyini düşük olarak algılayan ergenlerin, sosyoekonomik düzeyini yüksek olarak algılayan ergenlere göre daha çok riskli davranışlar sergiledikleri söylenebilir. Ergenlerin riskli davranışlarının alt boyutlarına bakıldığında; antisosyal davranışlar $\left(F_{(2,443)}=6.20, p<.01, \Omega^{2}=.12\right)$, alkol kullanımı $\left(F_{(2,443)}=7.47, p<.01, \Omega^{2}=.13\right)$, sigara kullanımı $\left(F_{(2,443)}=11.81, p<.01, \Omega^{2}=.13\right)$, intihar eğilimi $\left(F_{(2,443)}=3.29, p<.05, \Omega^{2}=.10\right)$, beslenme alışkanlıkları $\left(F_{(2,443)}=6.21, p<.01, \Omega^{2}=.12\right)$ ve okul terki $\left(F_{(2,443)}=11.63, p<.01, \Omega^{2}=.13\right)$ puanlarının algıladıkları sosyoekonomik düzeylerine göre anlamlı düzeyde farklılaşmakta olduğu görülmektedir. Ayrıca algılanan sosyoekonomik düzeyin, ergenlerin toplam riskli davranış $\left(\Omega^{2}=.13\right)$, antisosyal davranışlar $\left(\Omega^{2}=.12\right)$, alkol kullanımı $\left(\Omega^{2}=.13\right)$, sigara kullanımı $\left(\Omega^{2}=.13\right)$, intihar eğilimi $\left(\Omega^{2}=.10\right)$, beslenme alışkanlıkları $\left(\Omega^{2}=.12\right)$ ve okul terki $\left(\Omega^{2}=.13\right)$ puan ortalamaları üzerindeki etki büyüklüğünün orta düzeyde olduğu anlaşılmaktadır (Kirk, 1996).

Ergenlerin aile yapılarına göre riskli davranış puanları arasındaki farkın anlamlı olup olmadığını saptamaya yönelik tek yönlü varyans analizi yapılmış, sonuçlar Tablo 9'da gösterilmiştir. 
Tablo 8.

Ergenlerin Algıladıkları Sosyoekonomik Düzeylerine Göre Riskli Davranış Puanlarının Incelenmesine Ilişkin Tek Yönlü Varyans Analizi Sonuçları.

\begin{tabular}{|c|c|c|c|c|c|c|c|c|}
\hline & SED & $\mathbf{n}$ & $\bar{x}$ & S & $\mathbf{F}$ & $p$ & Fark & $\Omega^{2}$ \\
\hline Toplam Riskli & Düşük (A) & 89 & 104.31 & 28.85 & $14.36 * *$ & .00 & $A-B$ & .13 \\
\hline \multirow[t]{2}{*}{ Davranışlar } & Orta (B) & 176 & 80.89 & 26.08 & & & $B-C$ & \\
\hline & İyi (C) & 181 & 74.87 & 21.61 & & & $A-C$ & \\
\hline Antisosyal & Düşük (A) & 89 & 20.63 & 7.38 & $6.20 * *$ & .00 & $A-B$ & .12 \\
\hline \multirow[t]{2}{*}{ Davranışlar } & Orta (B) & 176 & 16.47 & 6.58 & & & $B-C$ & \\
\hline & İyi (C) & 181 & 15.42 & 6.25 & & & $A-C$ & \\
\hline \multirow[t]{3}{*}{ Alkol Kullanımı } & Düşük (A) & 89 & 16.89 & 8.43 & $7.47^{* *}$ & .00 & $A-B$ & .13 \\
\hline & Orta (B) & 176 & 11.93 & 7.47 & & & $B-C$ & \\
\hline & İyi (C) & 181 & 10.80 & 5.97 & & & $A-C$ & \\
\hline \multirow[t]{3}{*}{ Sigara Kullanımı } & Düşük (A) & 89 & 17.63 & 6.91 & $11.81 * *$ & .00 & $A-B$ & .13 \\
\hline & Orta (B) & 176 & 12.38 & 6.10 & & & $B-C$ & \\
\hline & İyi (C) & 181 & 10.23 & 5.12 & & & $A-C$ & \\
\hline \multirow[t]{3}{*}{ İntihar Eğilimi } & Düşük (A) & 89 & 17.31 & 4.89 & $3.29 *$ & .03 & $A-B$ & .10 \\
\hline & Orta (B) & 176 & 14.84 & 4.89 & & & $B-C$ & \\
\hline & İyi (C) & 181 & 13.38 & 4.88 & & & $A-C$ & \\
\hline Beslenme & Düşük (A) & 89 & 17.84 & 7.91 & $6.21 * *$ & .00 & $A-B$ & .12 \\
\hline \multirow[t]{2}{*}{ Alışkanlıkları } & Orta (B) & 176 & 13.45 & 6.57 & & & $B-C$ & \\
\hline & İyi (C) & 181 & 11.94 & 5.98 & & & $A-C$ & \\
\hline \multirow[t]{3}{*}{ Okul Terki } & Düşük (A) & 89 & 18.63 & 7.54 & $11.63 * *$ & .00 & $A-B$ & .13 \\
\hline & Orta (B) & 176 & 12.56 & 6.40 & & & $B-C$ & \\
\hline & İyi (C) & 181 & 11.45 & 6.16 & & & $A-C$ & \\
\hline
\end{tabular}

$* * \mathrm{p}<.01, * \mathrm{p}<.05$

Tablo 9.

Ergenlerin Aile Yapılarına Göre Riskli Davranış Puanlarının Incelenmesine Illişkin Tek Yönlü Varyans Analizi Sonuçları.

\begin{tabular}{|c|c|c|c|c|c|c|c|c|}
\hline & Aile Yapısı & $\mathbf{n}$ & $\bar{x}$ & $\mathbf{S}$ & $\mathbf{F}$ & $\mathbf{p}$ & Fark & $\Omega^{2}$ \\
\hline \multirow{3}{*}{$\begin{array}{l}\text { Toplam Riskli } \\
\text { Davranışlar }\end{array}$} & Anne-baba birlikte (A) & 206 & 77.11 & 24.03 & $9.85^{* *}$ & .00 & $A-B$ & .12 \\
\hline & Anne-baba ayrı (B) & 143 & 86.48 & 26.11 & & & $A-C$ & \\
\hline & Anne ve/veya baba ölü (C) & 97 & 100.52 & 26.57 & & & & \\
\hline \multirow{4}{*}{$\begin{array}{l}\text { Antisosyal } \\
\text { Davranışlar }\end{array}$} & Anne-baba birlikte $(A)$ & 206 & 15.88 & 6.47 & $5.03 * *$ & .00 & $A-B$ & .10 \\
\hline & Anne-baba ayrı (B) & 143 & 16.46 & 6.20 & & & $A-C$ & \\
\hline & Anne ve/veya baba ölü (C) & 97 & 20.94 & 7.11 & & & & \\
\hline & Anne-baba birlikte $(A)$ & 206 & 11.13 & 6.60 & $6.24 * *$ & .00 & $A-B$ & .11 \\
\hline \multirow[t]{3}{*}{ Alkol Kullanımı } & Anne-baba ayrı (B) & 143 & 14.13 & 8.14 & & & $A-C$ & \\
\hline & Anne ve/veya baba ölü (C) & 97 & 15.23 & 8.46 & & & & \\
\hline & Anne-baba birlikte $(A)$ & 206 & 11.58 & 5.49 & $10.75 * *$ & .00 & $A-B$ & .13 \\
\hline \multirow[t]{3}{*}{ Sigara Kullanımı } & Anne-baba ayrı (B) & 143 & 14.23 & 7.05 & & & $A-C$ & \\
\hline & Anne ve/veya baba ölü (C) & 97 & 16.94 & 6.26 & & & & \\
\hline & Anne-baba birlikte (A) & 206 & 14.39 & 4.87 & $7.01 * *$ & .00 & $A-B$ & .12 \\
\hline \multirow[t]{2}{*}{ İntihar Eğilimi } & Anne-baba ayrı (B) & 143 & 16.46 & 5.01 & & & $A-C$ & \\
\hline & Anne ve/veya baba ölü (C) & 97 & 17.76 & 3.57 & & & & \\
\hline \multirow{4}{*}{$\begin{array}{l}\text { Beslenme } \\
\text { Alışkanlıkları }\end{array}$} & Anne-baba birlikte $(A)$ & 206 & 11.54 & 5.56 & $6.45^{* *}$ & .00 & $A-B$ & .11 \\
\hline & Anne-baba ayrı (B) & 143 & 13.78 & 6.98 & & & $A-C$ & \\
\hline & Anne ve/veya baba ölü (C) & 97 & 16.27 & 7.14 & & & & \\
\hline & Anne-baba birlikte $(\mathrm{A})$ & 206 & 11.98 & 6.41 & $4.82 * *$ & .00 & $A-B$ & .09 \\
\hline \multirow[t]{2}{*}{ Okul Terki } & Anne-baba ayrı (B) & 143 & 13.13 & 6.37 & & & $A-C$ & \\
\hline & Anne ve/veya baba ölü (C) & 97 & 16.70 & 6.99 & & & & \\
\hline
\end{tabular}


Tablo 9'da görüldüğü üzere ergenlerin aile yapıları ile toplam riskli davranış puanları arasında bulunan fark istatistiksel olarak anlamlıdır $\left(F_{(2,443)}=9.85, p<.01, \Omega^{2}=.12\right)$. Buna göre, "anne-babası ayrı" ve "anne ve/veya babası ölü" olan ergenlerin, anne-babası birlikte olan ergenlere göre daha çok riskli davranışlar sergiledikleri söylenebilir. Ergenlerin riskli davranışlarının alt boyutlarına bakıldığında; anti sosyal davranışlar $\left(F_{(2,443)}=5.03, p<.01, \Omega^{2}=.10\right)$, alkol kullanımı $\left(F_{(2,443)}=6.24, p<.01, \Omega^{2}=.11\right)$, sigara kullanımı $\left(F_{(2,443)}=10.75, p<.01, \Omega^{2}=.13\right)$, intihar eğilimi $\left(F_{(2,443)}=7.01, p<.01, \Omega^{2}=.12\right)$, beslenme alışkanlıkları $\left(F_{(2,443)}=6.45, p<.01, \Omega^{2}=.11\right)$ ve okul terki $\left(F_{(2,443)}=4.82, p<.01, \Omega^{2}=.09\right)$ puanlarının aile yapılarına göre anlamlı düzeyde farklılaşmakta olduğu görülmektedir. Ayrıca algılanan sosyoekonomik düzeyin, ergenlerin toplam riskli davranışlar $\left(\Omega^{2}=.12\right)$, anti sosyal davranışlar $\left(\Omega^{2}=.10\right)$, alkol kullanımı $(\Omega 2=.11)$, sigara kullanımı $\left(\Omega^{2}=.13\right)$, intihar eğilimi $\left(\Omega^{2}=.19\right)$, beslenme alışkanlıkları $\left(\Omega^{2}=.11\right)$ ve okul terki $\left(\Omega^{2}=.09\right)$ puan ortalamaları üzerindeki etki büyüklüğünün orta düzeyde olduğu anlaşılmaktadır (Kirk, 1996).

\section{Sonuç ve Tartışma}

Araştırmada elde edilen bulgular alt problemlerdeki sırayla ele alındığında ilk olarak, öğretmen istismarı ve okul tükenmişliği değişkenleri ergenlerin riskli davranışları üzerinde pozitif yönde anlamlı düzeyde bir yordayıcı iken; okula bağlanmanın ise negatif yönde anlamlı bir yordayıcı olduğu görülmüştür.

Araştırmanın, ergenlerin riskli davranışları ile öğretmen istismarı arasında pozitif yönde anlamlı düzeyde bir ilişki olduğu şeklindeki bulgusu bazı çalışmalar tarafından desteklenmektedir (Cansız, 2019). Ayrıca, öğretmen istismarı ile okulu reddetme, kendini ve başkalarını olumsuz algılama (King \& Janson, 2011), saldırganlık ve dürtüsellikte artış (McEachern, Aluede, \& Kenny, 2008) gibi problem davranışlar arasında ilişki olduğu görülmektedir. Genel anlamda istismarın olumsuz etkileri gözönüne alındığında da, istismar yaşantısı arttıkça riskli davranışlara yönelimin arttığı (Arnow, 2004; Chen \& Liao, 2005; Fry et al. 2012); depresyon, intihar, alkol bağımlılığı, madde bağımlılığı ve kaygı bozuklukları gibi birçok psikolojik problem açısından maruz kalınan istismarın risk faktörü olduğu görülmüştür (Young \& Widom, 2014). Bu sonuçların, bu araştırmanın bulgularıyla paralellik gösterdiği görülmektedir.

Ergenlerde istismara maruz kalmak fiziksel, zihinsel, duygusal ya da seksüel son derece olumsuz deneyimleri içermektedir. Bu yaşantılar, istemsiz de olsa zaman zaman ergenin aklına gelerek bir dizi olumsuz ve derin duygunun yaşanmasına neden olmaktadır. Yaşanan bu duygusal acı ve sıkıntı ile birlikte, yüksek kaygı düzeyi, yalnızlık, suçluluk ve utanç, olumsuz kendilik algısı, ihanete uğramışlık hissi, öfke, nefret, değersizlik ve çaresizlik ile başa çıkmaya çalışan ergenler; bu duygulardan kurtulmak için sıklıkla riskli davranışlara yönelebilmektedir (Favazza, 1992; Ögel et al., 2007). Ayrıca istismar ve ihmalin yarattığı duyguları bastırma ve bu duygularla baş etmede yaşanan yetersizliğin, ergenlerde riskli davranışlara yönelimi artırdığı vurgulanmaktadır (Ögel et al., 2007). Bu bağlamda, ergenlerde istismar yaşantıları açısından, öğretmenler oldukça önemli bir konuma sahiptir. Öğretmen öğrenci ilişkisinin istismarın doğasında yer alan güç ilişkisine dayandığı ve bazı öğretmenlerin bu güçlerini ergenler üzerinde olumsuz yönde kullanma eğilimi gösterdiği bilinen bir durumdur. Bu açıdan araştırmanın bu bulgusu, öğrencilerin öğretmen istismarı ve riskli davranışlar açısından risk altında olduğunu göstermektedir.

Araştırmanın regresyon sonuçlarında yer alan ikinci bulgu ise okul tükenmişliğinin ergenlerin riskli davranışlarını pozitif yönde anlamlı düzeyde yordadığıdır. Ergenlerdeki riskli davranışlar ile okul tükenmişliği arasında ilişkinin olduğu, literatürdeki diğer çalışmalarda da benzer şekilde vurgulanmaktadır (Salmela-Aro \& Upadyaya, 2014; Yang \& Farn, 2005). Bu çalışmalarda, okul tükenmişliğinin olumsuz sonuçları ile ilgili olarak öğrencilerde; anksiyete ve korku (Maslach, 2003), yüksek stres düzeyi, depresyon (Salmela-Aro et al., 2009), artan dürtüsellik (Luo, Wang, Zhang, Chen, \& Quan, 2016), psikolojik uyumsuzluk (Lee \& Lee, 2018) gibi sorunlar yer almaktadır. Ayrıca, okul tükenmişliği okula devamsızlığın, derslere ilgi ve motivasyonun düşmesi ile okulu terk oranının artması (Yang \& Farn, 2005) nedeniyle madde kullanımı gibi diğer riskli davranışların ortaya çıkması açısından da önemli bir risk faktörü olarak görülmektedir. Tüm bu sonuçların yanı sıra okul tükenmişliğinin, okula 
uyum sağlama (Choi \& Lee, 2014), benlik saygısı (Luo et al., 2016), başarı hedefleri ve akademik başa çıkma (Shih, 2015) gibi olumlu durumlarla negatif; akılcı olmayan inançlar (Uzun \& Kemerli, 2019) gibi olumsuz zihinsel süreçlerle ise pozitif yönde ilişki göstermesi; pozitif ergen gelişimi açısından risk oluşturduğunu göstermektedir. Bu doğrultuda okullarda, okul tükenmişliğinin önlenmesine dair yapılan çalışmaların aynı zamanda riskli davranışların önlenmesine de katkı sağlayacağı düşünülmektedir.

Araştırmanın regresyon sonuçlarında yer alan bir diğer bulgu ise okula bağlanma düzeyinin, ergenlerin riskli davranışlarını negatif yönde anlamlı düzeyde yordadığı şeklindedir. Alanyazın incelendiğinde bazı çalışmalarda da benzer şekilde okula bağlanma arttıkça riskli davranışların azaldığına dair bulgulara ulaşılmıştır (Catalano, Haggerty, Oesterle, Fleming, \& Hawkins, 2004; Diaz, 2005; Şimşek \& Çöplü, 2018). Bu çalışmalarda yüksek düzeyde okula bağlanma, ergenlerin yaşam kalitesinin artması (Savi-Çakar, 2011b), alkol kullanma niyeti (Henry \& Slater, 2007), suç işleme ve riskli davranışlara yönelme (Rudasill et al., 2010) oranlarının düşük olması ile pozitif yönde anlamlı düzeyde ilişkili bulunmaktadır. Ayrıca düşük düzeyde okula bağlanma, ergenlerde duygusal ve davranışsal sorunlarda artış ile ilişkiliyken; yüksek düzeyde okula bağlanma psikolojik sağlamlık ile pozitif yönde ilişkilidir (SaviÇakar, 2018). Bu sonuçlar doğrultusunda, riskli davranışlar sergileyen ergenlere yönelik müdahale çalışmalarında; okula bağlanma düzeyinin arttırılmasına yönelik etkinlikler yapılmasının oldukça işlevsel olabileceği söylenebilir. Nitekim önemli bir psikososyal yapı olarak okul, duygusal ve bilişsel olarak bağlanmanın yanı sıra kendini okula ait hissetme, destek alma ve okul ortamına aktif katılım (Jimerson, Campos, \& Greif, 2003) ile ergenlerde psikolojik ve sosyal uyum açısından önemli bir koruyucu faktör olarak değerlendirilebilir.

Araştırmada elde edilen bir diğer bulgu ise riskli davranışların cinsiyete göre anlamlı düzeyde farklılık gösterdiğidir. Bu bağlamda erkek ergenlerin toplam riskli davranışlar, antisosyal davranışlar, alkol kullanımı, sigara kullanımı, sağlıksız beslenme alışkanlıkları ve okul terki puanlarının kızlardan daha yüksek olduğu belirlenmiştir. İlgili literatür incelendiğinde bu sonuçların bazı araştırma sonuçları ile benzer olduğu görülmektedir (Akanni, Koleoso, Olashore, Adayonfo, Osundina, \& Ayilara, 2017; Brady, Song, \& Halpern-Felsher, 2008; Karayağız-Muslu \& Aygün, 2017; Şimşek \& Çöplü, 2018). Bu çalışmalarda erkeklerde antisosyal davranışların daha fazla prevalans gösterdiği (Akyüz, 2019; Pérez-Fuentes et al., 2011); madde bağımlılı̆̆, okul terki ve genel riskli davranışların yanı sıra; alkol ve sigara ile diğer madde kullanımlarının kızlardan daha yüksek olduğu saptanmıştır (Akyüz, 2019; Brady et al., 2008). Ayrıca, suç işleme ve saldırganlık (Aydın \& Akgün, 2014); trafikte madde kullanımı ve toplumsal konumla ilgili risk almada da erkeklerin ortalamaları daha yüksektir (Karahan, Sardoğan, Gençoğlu, \& Yılan, 2006). Kaya, Bilgin ve Singer'in (2012) çalışmalarında da, erkek ergenlerde şiddet, zorbalık ve kontrolsüz öfke patlamaları gibi istenmeyen davranışların kızlara göre daha yaygın olduğu belirlenmiştir. Cinsiyete ilişkin farklılık, davranış sorunları açısından ele alındığında; kızlarda içselleştirme davranış problemlerinin erkeklerde ise dışsallaştırma davranış problemlerinin daha yaygın olduğu görülmektedir (Savi-Çakar, 2008; Şimşek, Erol, Öztop, \& Özer-Özcan, 2008). Tüm bu sonuçlara dayanarak, ergenlerde riskli davranışların cinsiyete göre farklılaşmasına ilişkin farklı açıklamaların olduğu söylenebilir. Bu açıklamalardan toplumsal cinsiyet rolleri ve kültürel faktörlerin etkisini vurgulayan (Hagan, Simpson, \& Gills, 1987) görüşlerde; toplumda var olan cinsiyete ilişkin yüklemelerin kadınlarda edilgenliği, erkeklerde ise bağımsızlık (Dökmen, 2019), korkusuzluk, güçlü ve sert olma gibi rolleri pekiştirdiği (Sancar, 2017) ve bu durumun erkek ergenlerde riskli davranışlarla ilişkili olabileceği belirtilmektedir. Ayrıca ergenlikte artan güç gösterisi ve risk alma eğiliminin (Gardner \& Steinberg, 2005) erkek ergenler üzerinde kızlara göre daha etkili bir rol oynadığı vurgulanmaktadır (Botdorf, Rosenbaum, Patrianakos, Steinberg, \& Chein, 2017). Bu açıklamaların yanı sıra erkeklerde saldırganlığı ve dışa yönelimi artıran biyolojik faktörler ile androjen ve testosteron hormonunun ve beyin ödül sisteminin riskli davranışlarla ilişkili olabileceği göz ardı edilmemelidir (Chein, Albert, O’Brien, Uckert, \& Steinberg, 2011).

Diğer taraftan bu araştırmada intihar eğilimi açısından kız ve erkek ergenler arasında anlamlı düzeyde bir farklılık olmadığı belirlenmiştir. Literatürde ise ağırıklı olarak kadın ergenlerde intihar eğiliminin daha yüksek olduğunu ortaya koyan çalışmalar yer almaktadır (Akın \& Berkem, 2012; Akyüz, 2019; Hawton, 2000; Jiang, Perry, \& Hesser, 2010; Savi-Çakar, Girgin, \& Uzun, 2020; Ulusoy, Demir, \& Baran, 2005). 
Zhang, Lei, Song, Lu, Duan ve Prochaska (2019) tarafından yapılan çalışmada da, intihar düşüncesinin yaygınlığı kızlarda erkeklerden anlamlı derecede yüksek bulunmuştur. Bu kapsamda bu araştırmanında sonucuna dayanarak, intihar eğilimi açısından yüksek riskli gruplara yönelik ve cinsiyete özgü intiharı önleme hedeflerinin oluşturulmasının önemine dikkat çekilmektedir.

Bu araştırmada elde edilen intihar eğilimi açısından kız ve erkek ergenler arasında anlamlı düzeyde bir farklılık olmadığı bulgusu, intihar sürecinde cinsiyetin rolüne ilişkin daha kapsamlı bir değerlendirmeye gereksinim duyulduğunu göstermektedir. Nitekim ergen intiharlarının çok boyutlu ve karmaşık yapısı göz önüne alındı̆̆ında, kız ve erkek ergenlerde intihar sürecinde cinsiyetin etkisini anlamak bu çalışmada çok mümkün olamamıştır. Diğer taraftan Durak-Batıgün (2008), intihar davranışları konusunda cinsiyetler arasında gözlenen farklılıkların açıklanmasında, her iki cinsiyet için de farklı değişkenlerin yordayıcı olabileceğini vurgulamaktadır. Nitekim Durak-Batıgün'ün (2008) çalışmasında, kişiler arası iletişim tarzları, yaşamı sürdürme nedenleri, umutsuzluk ve yalnızlık gibi değişkenlerin; kadın ve erkeklerde intiharı farklı düzeylerde yordadığı belirlenmiştir. Bu noktada intihar sürecini anlamaya çalışırken, kadınlar ve erkeklerin cinsiyet rolleri ile ilişkili diğer değişkenlerinde önemli olduğu düşünülerek; ergen intiharlarının doğasını anlamaya yönelik farklı araştırma süreçlerinin planlandığı çalışmalarla, cinsiyetin rolü değerlendirilmelidir. Tüm bu sonuçlar genel olarak değerlendirildiğinde, riskli davranışların cinsiyete göre farklılaştığı bulgular ağırlıkta olsa da; günümüzde birçok alanda olduğu gibi cinsiyet faktörünün riskli davranışlar içinde belirleyiciliğinin azaldığı ve kızlarda riskli davranış görülme oranının erkeklerle benzerlik gösterdiği ifade edilmektedir (Tharp-Taylor, Haviland, \& D'Amico, 2009). Bu kapsamda riskli davranışlar konusunda cinsiyete ilişkin boylamsal çalışmalara ihtiyaç duyulduğu düşünülmektedir.

Araştırmada elde edilen bir diğer bulgu ise riskli davranışların, ergenlerin sınıf düzeylerine göre anlamlı düzeyde farklılık gösterdiği şeklindedir. Bu bağlamda 12. sınıf öğrencilerinin toplam riskli davranışları, alkol kullanımı, sigara kullanımı ve beslenme alışkanlıkları puanlarının 9. sınıflara göre daha yüksek olduğu; ancak ergenlerin antisosyal davranışları, intihar eğilimleri ve okul terklerinin ise sınıf düzeylerine göre anlamlı düzeyde farklılaşmadığı belirlenmiştir. Literatür incelendiğinde bu bulgunun, ergenlerde sınıf düzeyi arttıkça riskli davranışların da arttı̆̆ını ortaya koyan araştırmaların bulguları tarafından desteklendiği görülmektedir (Öngören, Sarıefe, \& Balcı, 2017; Şimşek \& Çöplü, 2018). 12. sınıf öğrencilerinin yaş olarak 9. sınıflardan büyük olması ve yaşla birlikte riskli davranışlarda artış olduğunu ortaya koyan araştırmaların sonuçları ile de tutarlıdır (Öngören et al., 2017). Ayrıca, antisosyal davranışların prevalansının yaş ve okul yılı ile birlikte arttığı (Pérez-Fuentes et al., 2011), son sınıf öğrencisi ergenlerde riskli davranışlara yönelimin daha yüksek olduğu belirlenmiştir (Karayağız-Muslu \& Aygün, 2017). Ergenlerde sınıf düzeyine göre riskli davranışlarda artışın olması, liselerde ergen riskli davranışlarını önleme ve müdahale çalışmalarının önemini ve var olan uygulamaların etkisini değerlendirme açısından da açıklayıcı olabilir. Çünkü ergenlikle birlikte artış gösteren riskli davranışların, 9. sınıftan itibaren yapılacak etkili önleyici çalışmalarda önemli bir yer tutması gerekmektedir. Bu bağlamda okul temelli müdahale çalışmalarıyla etkili önleme ve müdahale programlarının yaygınlaştırılmasıyla birlikte 12. sınıf düzeyinde bu sorunların büyük oranda azalması söz konusu olabilir. Araştırmanın bu sonucu okullarda bu konuda yeterli önleme ve müdahale çalışması yapılıp yapılmadığının ortaya koyulmasına ihtiyaç duyulduğunu göstermesi açısından önemli olabilir.

Araştırmada elde edilen bir diğer bulgu ise riskli davranışların, ergenlerin akademik ortalamalarına göre anlamlı düzeyde farklılık gösterdiğidir. Bu bağlamda akademik ortalaması 49 ve altında olan öğrencilerin, akademik ortalaması 85 ve üstü olan öğrencilere göre daha çok riskli davranışlar sergiledikleri; bu farklılığın hem toplam riskli davranışlarda hem de anti sosyal davranışlar, alkol kullanımı, sigara kullanımı, beslenme alışkanlıkları ve okul terkinde görüldüğü belirlenmiştir. Araştırmanın sonuçları ile benzer olan çalışmalarda da akademik başarı düştükçe riskli davranışlar ve risk alma davranışlarının arttığı (Siyez, 2009); antisosyal davranışlar ile akademik başarı arasında negatif yönde anlamlı bir ilişki olduğu (Girma et al., 2019) vurgulanmaktadır. Pérez-Fuentes vd. (2011) yaptıkları çalışmada, akademik başarısızlığın antisosyal davranışlar ve suç işleme ile pozitif yönde ilişkili olduğunu belirlemişlerdir. Ayrıca akademik başarısızlığın ergenlerde alkol ve sigara kullanım riskini artırdığı 
(Öngören et al., 2017) ortaya koyulmuştur. Benzer şekilde Akyüz (2019) tarafından yapılan çalışmada da akademik başarının kaybedilmesi/başarı kaybının, riskli davranışlar gösterme açısından önemli bir risk faktörü olduğu; herhangi bir nedenle akademik başarı kaybı yaşayan ergenlerin antisosyal davranışlar, madde bağımlılığı, okul terki ve genel riskli davranışlarının anlamlı düzeyde daha yüksek olduğu belirlenmiştir.

Ergenlerde düşük akademik başarının, düşük benlik saygısı, düşük okula katılım, öfke, yıkıcı davranışlar ve anti sosyal davranışlar ile ilişkili olduğu vurgulanırken; düşük akademik başarı benlik saygısında düşmeye, okula düşük düzeyde bağlılık, hayal kırıklığı, suçluluk ve antisosyal davranışlar ile sonuçlanmaktadır (Li \& Armstrong, 2009). Nitekim akademik başarısızlığın sorun davranışların habercisi olduğu; başarısız öğrencilerin anlamlı öğrenme etkinliklerine katılım sürelerinin azalması, saldırgan davranışların artması anlamına geleceği belirtilmektedir (Chen, Rubin, \& Li, 1997; Choi, 2007). Buna ek olarak, saldırgan çocuklar öğretmenler ve akranları ile olumsuz ilişkiler veya okul hakkında olumsuz duygular geliştirebilir ve bunun sonucunda akademik çalışmalar üzerinde çaba göstermeye daha az eğilimli olabilirler (Arnold, 1997). Bu sonuçlar ergenler için yeterli düzeyde akademik başarının, riskli davranışlara yönelimde koruyucu bir rol oynadığı şeklinde değerlendirilebilir. Bu doğrultuda, okul psikolojik danışma ve rehberlik hizmetleri kapsamında yapılacak eğitsel rehberlik çalışmaları ile ergenlerin riskli davranışlarının önlenmesine ve dolayısıyla ruh sağlığına olumlu yönde katkı sağlanabilir.

Araştırmada ayrıca, ergen riskli davranışlarından intihar eğiliminin akademik ortalamaya göre anlamlı düzeyde farklılaşmadığı belirlenmiştir. Bu konuda alanyazında yapılmış olan diğer çalışmalarda da bu sonuç desteklenmektedir. Akyüz'ün (2019) çalışmasında da intihar eğiliminin akademik başarı kaybına göre anlamlı düzeyde farklılık göstermediği sonucuna ulaşılmıştır. Diğer taraftan literatürde ergen intiharlarının risk faktörlerinin incelendiği çalışmalarda, akademik sorunların önemli bir etken olduğu vurgulanmaktadır (Xing et al., 2010). Gül, Yürümez ve Gül (2017) tarafında yapılan çalışmada da 15-18 yaş aralığındaki kız ergenlerin intihar girişimi nedenlerinden biri de akademik başarısızlık (\%6.30) olarak bulunmuştur. Bu sonuçlarında ortaya koyduğu gibi, ergen intiharlarında risk faktörleri değişkenlik ve çeşitlilik göstermektedir. Günümüzde giderek artan ergen intiharlarında rol oynayan çok faktörlü yapıyı anlama, etkili önleme ve müdahale çalışmalarının yapılabilmesi açısından akademik başarının ergen intiharları üzerindeki etkisinin araştırılmasının oldukça önemli olduğu düşünülmektedir. Bu nedenle akademik sorunlar yaşayan ergenlerin, riskli davranışlar açısından çok yönlü olarak değerlendirilmesi gerekmektedir.

Araştırmada elde edilen bir diğer bulgu ise riskli davranışların, ergenlerin ailelerine dair algıladıkları sosyoekonomik durumlarına göre anlamlı düzeyde farklılık gösterdiğidir. Ailesinin sosyoekonomik düzeyini düşük olarak tanımlayan ergenlerin, yüksek olarak tanımlayanlara göre daha çok riskli davranışlar sergiledikleri; hem toplam riskli davranışlar hem de anti sosyal davranışlar, alkol kullanımı, sigara kullanımı, intihar eğilimi, beslenme alışkanlıkları ve okul terkinin algılanan sosyoekonomik düzeye göre anlamlı oranda farklılaştığı belirlenmiştir. Bu bulgunun literatürde bazı çalışmalar tarafından desteklendiği (Çavuş, Çavuş, \& Görpelioğlu, 2017; Wilkinson \& Marmot, 2003); ailede sosyoekonomik stres düzeyi arttıkça çocukların problem davranışlarının da arttığı görülmektedir (Borghol et al., 2012). Ergen riskli davranışları açısından önemli bir risk faktörü olan düşük sosyoekonomik düzey; aynı zamanda aile içi şiddet, çocuk istismarı, şiddetli aile içi çatışmalar ve madde kullanımı gibi sorunlar içinde önemli bir risk faktörüdür (Çavuş et al., 2017). Nitekim ergen riskli davranışlarını önlemede, ailenin ekonomik ve sosyal yapısı ile anne babanın eğitim durumu ergenlerin gelişimine olumlu katlı sağlayabilir. Ayrıca yüksek sosyoekonomik koşulların, ergeni olumsuz çevre baskıları, kötü alışkanlıklar ve riskli davranışlara karşı koruduğu belirtilmektedir (Greydanus \& Patel, 2003). Nitekim ebeveyn eğitim düzeyi ve aile gelir düzeyi arttıkça riskli davranışlara yönelimin azaldığını ortaya koyan çalışmalarda bunu desteklemektedir (Karayağız-Muslu \& Aygün, 2017).

Diğer taraftan alanyazında yer alan tüm bu bulguların ve açıklamaların aksine; ailelerin yüksek ekonomik gelir seviyesine sahip olması durumunun, ergenlerdeki riskli davranışlar açısından risk faktörü olduğu ve yüksek gelirli aileye sahip olan ergenlerde riskli davranışların arttığı belirtilmektedir (Aras, Günay, Özan, \& Orçın, 2007; Elgar et al., 2013; Öngören et al., 2017). Bu durum, ailenin sosyoekonomik 
ve sosyokültürel düzeyinin yükselmesi ile artan imkânlarının, ebeveynlerin ergenler üzerindeki denetimsizliğini arttırdı̆̆ı; devam eden süreçte bu durumun kendisini madde kötüye kullanımı, madde bağımlılığı ve alkol kullanımının yanı sıra risk alma davranışlarında (Akca \& Selen, 2016) ve anti sosyal davranışlarda (Aras et al., 2007; Çavuş et al., 2017) artış olarak gösterdiği vurgulanmaktadır. Diğer taraftan, riskli davranışların aile gelir düzeyi ve ebeveyn eğitimine göre farklılaşmadığını ortaya koyan çalışmalarda bulunmaktadır (Akca \& Selen, 2016). Bu sonuçlar ailenin sosyoekonomik düzeyinin ergenlerin riskli davranışları açısından önemli bir faktör olduğunu ortaya koymaktadır. Buna göre, ailenin sosyoekonomik yapısının ergenlerin hangi tür riskli davranışları üzerinde ve nasıl bir etkiye sahip olduğunun belirlenmesine yönelik çalışmaların önemli olduğu görülmektedir.

Araştırmada elde edilen bir diğer bulgu ise riskli davranışların ergenlerin aile yapısına göre anlamlı düzeyde farklılık gösterdiğidir. Bu bağlamda "anne-babası ayrı" ve "anne ve/veya babası ölmüş" olan ergenlerin, "anne-babası birlikte" olan ergenlere göre daha çok riskli davranışlar sergiledikleri belirlenmiştir. Bu farklılığın hem toplam riskli davranışlarda hem de antisosyal davranışlar, alkol kullanımı, sigara kullanımı, intihar eğilimi, beslenme alışkanlıkları ve okul terkinde ortaya çıktığı tespit edilmiştir. Bu bulgu, anne ve babanın ayrı olması ve anne babanın ölmüş olmasının, ergen riskli davranışları açısından önemli bir faktör olduğu; ergenlerde bu durumun kayıp ve yas süreci olarak değerlendirilerek, riskli davranışlara yönelimde ebeveyn kaybının (boşanma, ayrılık, ölüm ve terk edilme gibi farklı biçimlerde yaşanan durumları içeren tüm kayıplar) rolü olduğu şeklinde yorumlanabilir. Ebeveynin ölümü, çocuklar için normal gelişim sürecini engelleyebilecek kadar travmatik bir deneyim olmakla birlikte (Australian National University, 2020); yas sürecinde uyumsuz davranışlar ortaya çıkabilmektedir (Humphrey, 2009). İlgili çalışmalara bakıldığında, ebeveynlerin hayatta olup olmaması ile riskli davranışlar arasında anlamlı düzeyde bir ilişkinin bulunduğu görülmektedir. Alanyazında kayıp nedeniyle yas düzeyi yüksek olan ergenlerin, riskli davranışlar, madde bağımlılığı ve okul terkinin; yas yaşamayan veya düşük düzeyde yas yaşayanlara göre anlamlı düzeyde daha yüksek olduğu bulunmuştur (Akyüz, 2019). Ayrıca anne veya babası vefat eden ergenlerin, riskli davranışlar ve suça yönelik davranışları (Walker \& Shaffer, 2007), sigara kullanım riski ve intihar eğilimi daha yüksektir (Akyüz, 2019). Alanyazında, ebeveynlerini kaybeden erkek ergenlerde, uçucu madde kullanımının; kızlarda ise sigara ve madde kullanımının fazla olduğu ifade edilmektedir (Zisook \& Kendler, 2007). Yine, ebeveynleri boşanmış öğrencilerde de intihar eğilimi daha yüksektir (Öngören et al., 2017). Ergenlerin antisosyal davranışları üzerine yapılan araştırmalarda, genel olarak parçalanmış aile veya ergenin çocukluk dönemindeki ebeveyn kaybı dikkat çekmektedir. Ebeveyn kaybının yanı sıra boşanma ve ailenin ekonomik kayıpları; ergenlerin psikososyal uyumunun yanı sıra birçok alanda da olumsuz sonuçları arttırmaktadır (Griffiths, 2003). Yukarıdaki açıklamalarda da vurgulandığı gibi anne-babanın ayrılması veya anne ve/veya babanın ölmüş olması nedeniyle ortaya çıkan aile yapısındaki bu değişimlerle ergenin başa çıkamaması ve riskli davranışlara yönelmesi söz konusu olabilir.

\section{Öneriler}

Araştırmada elde edilen sonuçlara dayanarak şu öneriler sunulmaktadır:

- Ergenlerde riskli davranışları önlemeye yönelik olarak öğretmenlere, pozitif ergen gelişimini destekleme becerileri eğitimleri yapılabilir.

- Okul tükenmişliğini önlemenin ergenlerin riskli davranışlarını önlemeye de katkı sağlayacağı bulgusuna dayanarak, okul temelli önleme programları ile okul tükenmişliği önlenebilir.

- Okula bağlanmanın artırımasına yönelik psikoeğitim programları uygulanabilir.

- Okullarda, riskli davranışların erken uyarı işaretlerini belirmeye ve erken müdahale sistemi oluşturmaya yönelik çalışmaların yapııması yararlı olabilir.

- Ergenlerde sosyo ekonomik düzeye yönelik risk türlerinin belirlenmesi için araştırmalar yapılabilir.

- Ergenlerde akademik başarı ve riskli davranışlar arasındaki karşılıklı belirleyicilik göz önünde bulundurularak okullarda eğitsel rehberlik ve kişisel sosyal rehberlik çalışmalarına ağırlık verilebilir. 


\section{Sınırlılıklar}

$\mathrm{Bu}$ araştırmanın sonuçları, lise öğrencisi ergenler için riskli davranışlar ile okul tükenmişliği, öğretmenden algılanan istismar ve okula bağlanma arasında tutarlı ve güçlü ilişkiler olduğunu göstermiştir. Bulgular yorumlanırken bazı sınırlılıklar olduğu göz önünde bulundurulmalıdır. İlk olarak, bu çalışmanın kesitsel tasarımı nedeniyle, riskli davranışlar ile diğer faktörler arasındaki nedensel ilişkinin ortaya koyulamadığı unutulmamalıdır. Íkincisi, riskli davranışların ergenlerde problemli bir durumu temsil ettiği geleneksel görüşü ile önyargılı bir tutum sergilenmiş ve riskli davranışların ergenlerde olumlu bir amaca hizmet edeceği görüşü göz ardı edilmiştir. Üçüncüsü, araştırmanın kırsal alandaki yaşayan ergenleri yansıttığı söylenemez. Bu nedenle bulguların genellenebilmesi için bu gruplar hakkında daha fazla araştırmaya ihtiyaç vardır. 


\section{References}

Akanni, O. O., Koleoso, O. N., Olashore, A. A., Adayonfo, E. O., Osundina, A. F., \& Ayilara, O. O. (2017). Gender and other risk factors associated with risky behaviours among Nigerian adolescents. Journal of Adolescence, 57, 13-17. doi:10.1016/j.adolescence.2017.03.002

Akca, S. O. \& Selen, F. (2016). Erkek ergenlerde riskli davranışlar: Bir lise örneği. TAF Preventive Medicine Bulletin, 15(3), 206-212. doi:10.5455/pmb.1-1442334339

Akın, E. \& Berkem, M. (2012). İntihar girişiminde bulunan ergenlerde öfke ve dürtüsellik. Marmara Medical Journal, 25(3), 148-152. doi:10.5472/MMJ.2012.02473.1

Akyüz, G. A. (2019). Kayıp ve yas yaşantısı olan ve olmayan ergenlerde duygu düzenleme ve öznel iyi oluşun riskli davranışları yordama düzeyi. Unpublished master's thesis, Burdur Mehmet Akif Ersoy Üniversitesi Eğitim Bilimleri Enstitüsü, Burdur.

Albayrak, A. S. (2005). Çoklu doğrusal bağlantı halinde en küçük kareler tekniğinin alternatifi yanlı tahmin teknikleri ve bir uygulama. ZKÜ Sosyal Bilimler Dergisi, 1(1), 105-126.

Aras, Ş., Günay, T., Özan, S., \& Orçın, E. (2007). İzmir ilinde lise öğrencilerinin riskli davranışları. Anatolian Journal of Psychiatry, 8(3), 186-196.

Arnold, D. H. (1997). Co-occurrence of externalizing behavior problems and emergent academic difficulties in young high-risk boys: A preliminary evaluation of patterns and mechanisms. Journal of Applied Developmental Psychology, 18(3), 317-330. doi:10.1016/S0193-3973(97)80003-2

Arnow, B. A. (2004). Relationship between child maltreatment, adult health and psychiatric outcomes and medical utilisation. Journal of Clinical Psychiatry, 65, 10-15.

Australian National University (2020). Australıan child and adolescent trauma, loss and grief network. What is a Trauma Informed Approach? [Video file]. Retrieved from https://earlytraumagrief.anu.edu.au

Aydın, A. \& Akgün, S. (2014). Ergenlikte reaktif-proaktif saldırganlık, öfke ve narsisizm ilişkisi. Türk Psikoloji Dergisi, 29(73), 44-56.

Bandura, A. (2006). Toward a psychology of human agency. Perspectives on Psychological Science, 1(2), 164-180. doi:10.1111/j.1745-6916.2006.00011.x

Borghol, N., Suderman, M., McArdle, W., Racine, A., Hallett, M., Pembrey, M., ... \& Szyf, M. (2012). Associations with early-life socio-economic position in adult DNA methylation. International Journal of Epidemiology, 41(1), 62-74. doi:10.1093/ije/dyr147

Botdorf, M., Rosenbaum, G. M., Patrianakos, J., Steinberg, L., \& Chein, J. M. (2017). Adolescent risktaking is predicted by individual differences in cognitive control over emotional, but not nonemotional, response conflict. Cognition and Emotion, 31(5), 972-979. doi:10.1080/02699931.2016.1168285

Brady, S. S., Song, A. V., \& Halpern-Felsher, B. L. (2008). Adolescents report both positive and negative consequences of experimentation with cigarette use. Preventive Medicine: An International Journal Devoted to Practice and Theory, 46(6), 585-590. doi:10.1016/j.ypmed.2008.01.019

Brendgen, M., Lamarche, V., Wanner, B., \& Vitaro, F. (2010). Links between friendship relations and early adolescents' trajectories of depressed mood. Developmental Psychology, 46(2), 491-501. doi:10.1037/a0017413

Bronfenbrenner, U. (1979). The ecology of human development. Harvard University Press, USA.

Büyüköztürk, Ş. (2014). Sosyal bilimler için veri analizi el kitabı (19nd ed.). Ankara: PEGEM Akademi.

Büyüköztürk, Ş., Kılıç-Çakmak, E., Akgün, Ö.E., Karadeniz, Ş., \& Demirel, F. (2016). Bilimsel araştırma yöntemleri (21nd ed.). Ankara: Pegem Akademi. 
Campos, R. C. \& Mesquita, C. (2014). Testing a model of suicidality in community adolescents: A brief report. Journal of Child \& Adolescent Behavior, 2(147). doi:10.4172/jcalb.1000147

Cansız, C. (2019). Ergenlerde algılanan duygusal istismar ile kendine zarar verme davranışı ve riskli davranışlar arasındaki ilişki. Unpublished master's thesis, Burdur Mehmet Akif Ersoy Üniversitesi Eğitim Bilimleri Enstitüsü, Burdur.

Catalano, R. F., Haggerty, K. P., Oesterle, S., Fleming, C. B., \& Hawkins, J. D. (2004). The Importance of bonding to school for healthy development: Findings from the social development research group. Journal of School Health, 74(7), 252-261. doi:10.1111/j.1746-1561.2004.tb08281.x

Chein, J., Albert, D., O’Brien, L., Uckert, K., \& Steinberg, L. (2011). Peers increase adolescent risk taking by enhancing activity in the brain's reward circuitry. Developmental Science, 14(2), F1-F10. doi:10.1111/j.1467-7687.2010.01035.x

Chen, J. Q. \& Liao, W. (2005). Childhood humiliated experiences and its correlation with the mental health in technical secondary school students. Chinese Journal of School Health, 26(5), 355-357.

Chen, X., Rubin, K. H., \& Li, D. (1997). Relation between academic achievement and social adjustment: Evidence from Chinese children. Developmental Psychology, 33(3), 518-525. doi:10.1037/00121649.33.3.518

Choi, O. \& Lee, W. S. (2014). Mediating effects of self-efficacy in the relationships between academic burnout and school adjustment on middle school students. Journal of Digital Convergence, 12(9), 455-463. doi:10.14400/JDC.2014.12.9.455

Choi, Y. (2007). Academic achievement and problem behaviors among Asian Pacific Islander American adolescents. Journal of Youth and Adolescence, 36(4), 403-415. doi:10.1007/s10964-006-9152-4

Cohen, J. (1988). Statistical power analysis fort he behavioral sciences (2nd ed.). Hillsdale, NJ: Erlbaum.

Çataloğlu, B. (2011). Madde kullanan ve kullanmayan ergenlerin psikolojik sağlamlık, aile işlevleri açısından karşılaştırılması. Unpublished master's thesis, Dokuz Eylül Üniversitesi Eğitim Bilimleri Enstitüsü, İzmir.

Çavuş, F. Ö., Çavuş, U. Y., \& Görpelioğlu, S. (2017). Prevalence, distribution and influencing factors of risky behaviour in Ankara. Turkish Journal of Family Practice, 21(1), 2-16.

Çokluk, Ö., Şekercioğlu, G., \& Büyüköztürk, Ş. (2014). Sosyal bilimler için istatistik (3nd ed.). Ankara: Pegem Akademi.

Diaz, J. D. (2005). School attachment among latino youth in rural Minnesota. Hispanic Journal of Behavioral Sciences, 27(3), 300-318. doi:10.1177/0739986305276746

D'Onofrio, A. (2007). Adolescent self-injury: A comprehensive guide for counselors and health care professionals. New York: Springer Publishing Company.

Dökmen, Z. Y. (2019). Toplumsal cinsiyet, sosyal psikolojik açıklamalar (10nd ed.). İstanbul: Remzi Kitabevi.

Durak-Batıgün, A. (2008). İntihar olasılığı ve cinsiyet: Illetişim becerileri, yaşamı sürdürme nedenleri, yalnızlık ve umutsuzluk açısından bir inceleme. Türk Psikoloji Dergisi, 23(62), 65-75.

Eccles. J. S. \& Roeser, R. W. (1999). School and community influences on human development. In M. H. Boorstein \& M. E. Lamb (Eds.), Developmental psychology: An advanced textbook (2nd ed. pp. 503554). Hillsdale, NJ: Lawrence Erlbaum Associates.

Elgar, F. J., De Clercq, B., Schnohr, C. W., Bird, P., Pickett, K. E., Torsheim, T., ... \& Currie, C. (2013). Absolute and relative family affluence and psychosomatic symptoms in adolescents. Social Science \& Medicine, 91, 25-31. doi:10.1016/j.socscimed.2013.04.030

Faircloth, B. S. \& Hamm, J. V. (2005). Sense of belonging among high school students representing four ethnic groups. Journal of Youth and Adolescence, 34(4), 293-309. doi:10.1007/s10964-005-5752-7 
Favazza, A. R. (1992). Repetitive self-mutilation. Psychiatric Annals, 22(2), 60-63. doi:10.3928/00485713-19920201-06

Fields, A. (2005). Discovering statistics using SPSS (2nd ed.). Beverly Hills: Sage Publications.

Fry, D., McCoy, A., \& Swales, D. (2012). The consequences of maltreatment on children's lives: a systematic review of data from the East Asia and Pacific Region. Trauma, Violence, \& Abuse, 13(4), 209-233. doi:10.1177/1524838012455873

Gardner, M. \& Steinberg, L. (2005). Peer influence on risk taking, risk preference, and risky decision making in adolescence and adulthood: An experimental study. Developmental Psychology, 41(4), 625-635. doi:10.1037/0012-1649.41.4.625

Garnefski, N., Kraaij, V., \& Spinhoven, P. (2001). Negative life events, cognitive emotion regulation and emotional problems. Personality and Individual Differences, 30(8), 1311-1327. doi:10.1016/S01918869(00)00113-6

Gençtanırım, D. \& Ergene, T. (2014). Riskli davranışlar ölçeğinin geliştirilmesi: Geçerlik ve güvenirlik çalışmaları. International Journal of Social Science, 25(1), 125-138. doi:10.9761/JASSS2304

Gerard, J. M. \& Buehler, C. (2004). Cumulative environmental risk and youth problem behavior. Journal of Marriage and Family, 66(3), 702-720. doi:10.1111/j.0022-2445.2004.00048.x

Girma, H., Hassen, A., \& Garuma, D. (2019). Adolescents antisocial behavior and their academic performance: The case of high schools in jimma town. International Journal of Multicultural and Multireligious Understanding, 6(1), 110-122. doi:10.18415/ijmmu.v6i1.575.

Greydanus, D. E. \& Patel, D. R. (2003). Substance abuse in adolescents: A complex conundrum for the clinician. Pediatric Clinics of North America, 50(5), 1179-1223. doi:10.1016/s0031-3955(03)00079-8

Griffiths, M. (2003). Terms of engagement: Reaching hard to reach adolescents. Young Minds Magazine, 62, 23-26.

Gutman, L. M., Eccles, J. S., Peck, S., \& Malanchuk, O. (2011). The influence of family relations on trajectories of cigarette and alcohol use from early to late adolescence. Journal of Adolescence, 34(1), 119-128. doi:10.1016/j.adolescence.2010.01.005.

Gül, H., Yürümez, E., \& Gül, A. (2017). Ergenlerde ilk intihar girişimi: Dürtüsellik ve kötü çocukluk çağı yaşantıları arasındaki ilişki. Çocuk ve Gençlik Ruh Sağlığı Dergisi, 24(1), 45-53.

Hagan, J., Simpson, A. J., \& Gills. A. R. (1987). Class in the households: a power control theory of gender and delinquency. American Journal of Sociology, 92(4), 788-816. doi:10.1086/228583

Harden, K. P., Quinn, P. D., \& Tucker-Drob, E. M. (2012). Genetically influenced change in sensation seeking drives the rise of delinquent behavior during adolescence. Developmental Science, 15(1), 150-163. doi:10.1111/j.1467-7687.2011.01115.x

Hawton, K. (2000). Sex and suicide: Gender differences in suicidal behaviour. The British Journal of Psychiatry, 177(6), 484-485. doi:10.1192/bjp.177.6.484

Henry, K. L. \& Slater, M. D. (2007). The contextual effect of school attachment on young adolescents' alcohol use. Journal of School Health, 7(2), 67-74. doi:10.1111/j.1746-1561.2007.00169.x

Hill, L. G. \& Werner, N. E. (2006). Affiliative motivation, school attachment, and aggression in school. Psychology in the Schools, 43(2), 231-246. doi:10.1002/pits.20140

Hirschi, T. (2002). Causes of delinquency. Transaction Publishers. Retrieved from psycnet.apa.org/record/

Humphrey, K. M. (2009). Counseling strategies for loss and grief. Alexandria, VA: American Counseling Association.

Hyman, I. A. \& Snook, P. A. (1999). Dangerous schools: What we can do about the physical and emotional abuse of our children. San Francisco: Jossey-Bass. 
İkiz, E. F. \& Savi-Çakar, F. (2012). Psychology of adolescence. In L. Barış \& Ö. Uzun (Eds.), Behavior problems in relation perceived social support (pp. 1-48). New York: Nova Science Publishers, Inc.

Jessor, R. (1991). Risk behavior in adolescence: A psychosocial framework for understanding and action. Journal of Adolescent Health, 12(8), 597-605. doi:10.1016/1054-139X(91)90007

Jessor, R., Donovan, J.E., \& Costa, F.M. (1994). Beyond adolescence; problem behavior and young adult development. USA: Cambridge University Press.

Jiang, Y., Perry, D. K., \& Hesser, J. E. (2010). Adolescent suicide and health risk behaviors: Rhode Island's 2007 youth risk behavior survey. American Journal of Preventive Medicine, 38(5), 551-555. doi:10.1016/j.amepre.2010.01.019

Jimerson, S. R., Campos, E., \& Greif, J. L. (2003). Toward an understanding ofdefinitions and measures of school engagement and related terms. The California School Psychologist, 8(1), 7-27. doi:10.1007/BF03340893

Karahan, T. F., Sardoğan, M. E., Gençoğlu, C., \& Yılan, G. (2006). Lise öğrencilerinde trafik, madde kullanımı ve toplumsal konumla ilgili risk alma davranışı. Eğitim ve Bilim, 31(142), 72-79.

Karasar, N. (2012). Bilimsel araştırma yöntemi (24nd ed.). Ankara: Nobel Yayın Dağıtım.

Karayağız-Muslu, G. \& Aygün, Ö. (2017). Ergenlerin riskli sağık davranışlarını ve etkileyen faktörlerin belirlenmesi. Dokuz Eylül Üniversitesi Hemşirelik Fakültesi Elektronik Dergisi, 10(4), 242-250.

Kaya, F., Bilgin, H., \& Singer, M. I. (2012). Contributing factors to aggressive behaviors in high school students in Turkey. The Journal of School Nursing, 28(1), 56-69. doi:10.1177/1059840511418669

Kırımsoy, E. (2003). Suç işlemiş ve suç işlememiş ergenlerin algıladıkları duygusal istismar ve benlik saygılarının karşılaştırmalı olarak incelenmesi. Unpublished master's thesis, Ankara Üniversitesi Sosyal Bilimler Enstitüsü, Ankara.

King, M. A. \& Janson, G. R. (2011). Beware emotional maltreatment. Principal, 91(1), 18-21.

Kirk, R. E. (1996). Practical significance: A concept whose time has come. Educational and Psychological Measurement, 56, 746-759.

Kline, P. (2014). An easy guide to factor analysis. New York: Routledge.

Lee, M. Y. \& Lee, S. M. (2018). The effects of psychological maladjustments on predicting developmental trajectories of academic burnout. School Psychology International, 39(3), 217-233. doi:10.1177/0143034318766206

Li, H. \& Armstrong, D. (2009). Is there a correlation between academic achievement and behavior in Mainland Chinese students. Asian Social Science, 5(4), 3-5. doi:10.5539/ass.v5n4p3

Lindberg, L. D., Boggess, S., Porter, L., \& Williams, S. (2000). Teen risk taking: A statistical portrait. Washington, DC: Urban Institute.

Little, R. J. (1988). A test of missing completely at random for multivariate data with missing values. Journal of the American statistical Association, 83(404), 1198-1202. doi:10.1080/01621459.1988.10478722.

Luo, Y., Wang, Z., Zhang, H., Chen, A., \& Quan, S. (2016). The effect of perfectionism on school burnout among adolescence: The mediator of self-esteem and coping style. Personality and Individual Differences, 88, 202-208. doi:10.1016/j.paid.2015.08.056

Maslach, C. (2003). Job burnout: New directions in research and intervention. Current Directions in Psychological Science, 12(5), 189-192. doi:10.1111/1467-8721.01258

McEachern, A. G., Aluede, O., \& Kenny, M. C. (2008). Emotional abuse in the classroom: Implications and interventions for counselors. Journal of Counseling \& Development, 86(1), 3-10. doi:10.1002/j.15566678.2008.tb00619.x 
Mertler, C. A. \& Vannatta, R. A. (2005). Advanced and multivariate statistical methods: Practical application and interpretation (3nd ed.). CA: Pyrczak Publishing.

Ögel, K., Akço, S., Aksoy, A., Dönmez, E., Yılmazçetin, C. E., Erdoğan, N., \& Erol, B. (2007). Riskli davranışlar gösteren çocuk ve ergenler: Alanda çalışanlar için bilgiler. İstanbul: Yeniden Sağlık ve Eğitim Derneği.

Öngören, B., Sarıefe, H., \& Balcı, Y. (2017). Ergenlerde riskli davranışların sosyal açıdan irdelenmesi. International Journal of Social Science Studies, 62, 333-347, doi:10.9761/JASSS7294

Özdemir, S. (2018). Ergen riskli davranışlarının akran zorbalığı, örselenme yaşantıları ve psikolojik sağlamlık ile ilişkisinde sapkın arkadaşların aracı etkisinin incelenmesi. Eğitim ve Bilim, 43(195), 223239. doi:10.15390/EB.2018.7509

Özen, Y. \& Gül, A. (2007). Sosyal ve eğitim bilimleri araştırmalarında evren-örneklem sorunu. Atatürk Üniversitesi Kazım Karabekir Eğitim Fakültesi Dergisi, (15), 394-422.

Pérez-Fuentes, M. D. C., Gázquez, J. J. Mercader, I., \& García-Rubira, M. M. (2011). Academic achievement and antisocial behavior in public secondary education students. International Journal of Psychology and Psychological Therapy, 11(3), 401-412.

Perkins, D. F. \& Jones, K. R. (2004). Risk behaviors and resiliency within physically abused adolescents. Child Abuse \& Neglect, 28(5), 547-563. doi:10.1016/j.chiabu.2003.12.001

Piko, B. (2000). Perceived social support from parents and pers: which is the stronger predictor of adolescent substance use? Substance Use \& Misuse, 35(4), 617-630. doi:10.3109/10826080009147475

Quinn, P. D. \& Fromme, K. (2010). Self-regulation as a protective factor against risky drinking and sexual behavior. Psychology of Addictive Behaviors, 24(3), 376-385. doi:10.1037/a0018547

Roeser, R. W. \& Eccles, J. S. (2000). Schooling and mental health. In A. J. Sameroff, M. Lewis, \& S. M. Miller (Eds.), Handbook of developmental psychopathology (2nd ed., pp. 135-156). New York: Plenum.

Rudasill, K. M., Reio Jr, T. G., Stipanovic, N., \& Taylor, J. E. (2010). A longitudinal study of studentteacher relationship quality, difficult temperament, and risky behavior from childhood to early adolescence. Journal of School Psychology, 48(5), 389-412. doi:10.1016/j.jsp.2010.05.001

Salmela-Aro, K., Kiuru, N., Leskinen, E., \& Nurmi, J. E. (2009). School burnout inventory (SBI) reliability and validity. European Journal of Psychological Assessment, 25(1), 48-57. doi:10.1027/10155759.25.1.48

Salmela-Aro, K., Savolainen, H., \& Holopainen, L. (2009). Depressive symptoms and school burnout during adolescence: Evidence from two cross-lagged longitudinal studies. Journal of Youth and Adolescence, 38(10), 1316-1327. doi:10.1007/s10964-008-9334-3

Salmela-Aro, K. \& Upadyaya, K. (2014). Developmental trajectories of school burnout: Evidence from two longitudinal studies. Learning and Individual Differences, 36, 60-68. doi:10.1016/j.lindif.2014.10.016

Salmela-Aro, K., Upadyaya, K., Hakkarainen, K., Lonka, K., \& Alho, K. (2017). The dark side of internet use: Two longitudinal studies of excessive internet use, depressive symptoms, school burnout and engagement among Finnish early and late adolescents. Journal of Youth and Adolescence, 46(2), 343357. doi:10.1007/s10964-016-0494-2

Sancar, S. (2017). Türk modernleşmesinin cinsiyeti erkekler devlet, kadınlar aile kurar (4nd ed.). İstanbul: illetişim Yayınları.

Savi-Çakar, F. (2008). 12-15 yaş arası ilköğretim öğrencilerinin davranış sorunları ile aile işlevleri ve annebaba kişilik özellikleri arasındaki ilişki. Unpublished doctoral dissertation, Dokuz Eylül Üniversitesi Eğitim Bilimleri Enstitüsü, İzmir. 
Savi-Çakar, F. (2011a). Çocuk ve ergenler için okula bağlanma ölçeği: Geçerlik ve güvenirlik çalışması. ilköğretim Online, 10(1), 80-90.

Savi-Çakar, F. (2011b). School attachment and quality of life in children and adolescents of elementary school in Turkey. Education Research, 9(1), 1465-1471.

Savi-Çakar, F., Tagay, Ö., \& Karataş, Z. (2015). Adolescents' life satisfaction: Risky behaviors and hopelessness. International Journal on New Trends in Education and Their Implications, 6(1), 55-62.

Savi-Çakar, F. \& Tagay, Ö. (2017). The mediating role of self-esteem: The effects of social support and subjective well-being on adolescents' risky behaviors. Educational Sciences: Theory \& Practice, 17(3), 859-876. doi:10.12738/estp.2017.3.0024

Savi-Çakar, F. (2018). The relationship between adolescents' emotional-behavioral problems and their levels of resilience and school attachment. International Social Sciences Studies Journal, 4(26), 58045815.

Savi-Çakar, F. \& Kılınç, M. (2020). Ergenlerin psikolojik yardım ihtiyaçlarının incelenmesi. Mehmet Akif Ersoy Üniversitesi Eğitim Fakültesi Dergisi, (54), 488-508. doi:10.21764/ maeuefd.655097

Savi-Çakar, F., Girgin, M., \& Uzun, K. (2020). Ergenlerin intihar girişimlerinde risk faktörleri ve psikolojik yardım alma durumlarının incelenmesi. International Social Sciences Studies Journal, 6(68), 35993618. doi:10.26449/sssj. 2568

Seçer, i., Halmatov, S., Veyis, F., \& Ateş, B. (2013). Okul tükenmişlik ölçeğinin Türk kültürüne uyarlanması: Güvenirlik ve geçerlik çalışması. Turkish Journal of Education, 2(2), 16-27.

Shih, S. S. (2015). The relationships among Taiwanese adolescents' perceived classroom environment, academic coping, and burnout. School Psychology Quarterly, 30(2), 307-320. doi:10.1037/spq0000093

Siyez, D. M. (2009). Ergenlerde problem davranışlar okul temelli önleme çalışmaları ve ilgili uygulama örnekleri. Ankara: Pegem Akademi.

Şimşek, H. \& Çöplü, F. (2018). Lise öğrencilerinin riskli davranışlar gösterme düzeyleri ile okula bağlanma düzeyleri arasındaki ilişkinin incelenmesi. Ahi Evran Üniversitesi Sosyal Bilimler Enstitüsü Dergisi, 4(1), 18-30. doi:10.31592/aeusbed.358223

Şimşek, Z., Erol, N., Öztop, D., \& Özer-Özcan, Ö. (2008). Kurum bakımındaki çocuk ve ergenlerde davranış ve duygusal sorunların epidemiyolojisi; ulusal örneklemde karşılaştırmalı bir araştırma. Türk Psikiyatri Dergisi, 19(3), 235-244.

Tabachnick, B. G., Fidell, L. S., \& Ullman, J. B. (2007). Using multivariate statistics (5nd ed.). Boston, MA: Pearson.

Taner, Y. \& Gökler, B. (2004). Çocuk istismarı ve ihmali: Psikiyatrik yönleri. Acta Medica, 35(2), 82-86.

Tharp-Taylor, S., Haviland, A., \& D'Amico, E. J. (2009). Victimization from mental and physical bullying and substance use in early adolescence. Addictive Behaviors, 34(6-7), 561-567. doi:10.1016/j.addbeh.2009.03.012

Theoklitou, D., Kabitsis, N., \& Kabitsi, A. (2012). Physical and emotional abuse of primary school children by teachers. Child Abuse \& Neglect, 36(1), 64-70. doi:10.1016/j.chiabu.2011.05.007

Ulusoy, D., Demir, N. Ö., \& Baran, A. G. (2005). Ergenlik döneminde intihar algısı: Lise son sınıf gençliği örneği. Hacettepe Üniversitesi Edebiyat Fakültesi Dergisi, 22(1), 259-270.

Uzun, K. \& Karataş, Z. (2019). Okul tükenmişliğinin yordayıcısı olarak akran zorbalığı ve siber mağduriyet. Uluslararası Sosyal Araştırmalar Dergisi, 12(62), 1108-1118. doi:10.17719/jisr.2019.3123

Uzun, K. \& Kemerli, Ş. (2019). Ergenlerde okul tükenmişliğinin yordayıcısı olarak akılcı olmayan inançlar. Eğitim ve Öğretim Araştırmaları Dergisi, 8(1), 10-26.

Walker, P. \& Shaffer, M. (2007). Reducing depression among adolescents dealing with grief and loss: A program evaluation report. Health \& Social Work, 32(1), 67-68. doi:10.1093/hsw/32.1.67 
Wilkinson, R. \& Marmot, M. (2003). The social determinants of health: The solid facts (2nd ed.). WHO Regional Office for Europe.

World Health Organization (1999). The who Report 1999. Geneva: Making a difference.

Yang, H. J. \& Farn, C. K. (2005). An investigation the factors affecting MIS student burnout in technicalvocational college. Computers in Human Behavior, 21(6), 917-932. doi:10.1016/j.chb.2004.03.001

Young, J. C. \& Widom, C. S. (2014). Long-term effects of child abuse and neglect on emotion processing in adulthood. Child Abuse \& Neglect, 38(8), 1369-1381. doi:10.1016/j.chiabu.2014.03.008

Zhang, Y. Y., Lei, Y. T., Song, Y., Lu, R. R., Duan, J. L., \& Prochaska, J. J. (2019). Gender differences in suicidal ideation and health-risk behaviors among high school students in Beijing, China. J Glob Health, 9(1), 010604. doi:10.7189/jogh.09.010604

Zisook, S. \& Kendler, K. S. (2007). Is bereavement-related depression different than non-bereavementrelated depression?. Psychological medicine, 37, 779-794. doi:10.1017/\$0033291707009865

Xing, X. Y., Tao, F. B., Wan, Y. H., Xing, C., Qi, X. Y., Hao, J. H., ... \& Huang, L. (2010). Family factors associated with suicide attempts among Chinese adolescent students: a national cross-sectional survey. Journal of Adolescent Health, 46(6), 592-599. doi:10.1016/j.jadohealth.2009.12.006 